\title{
Seasonal and interannual variability of phytoplankton pigment in the Laccadive (Lakshadweep) Sea as observed by the Coastal Zone Color Scanner
}

\author{
Lisa JADE Lierheimer ${ }^{1}$ and KARL BANSE ${ }^{2}$ \\ ${ }^{1}$ U.S. Fish and Wildlife Service, Office of International Affairs, Division of Management Authority, \\ 4401 North Fairfax Drive, Arlington, VA 22046 \\ ${ }^{2}$ Corresponding author: School of Oceanography, Box 357940, University of Washington, Seattle, \\ WA 98195-7940, U.S.A. \\ e-mail: banse@ocean.washington.edu
}

\begin{abstract}
Based on Coastal Zone Color Scanner data from November 1978 through December 1981, the seasonal cycle of phytoplankton pigment in the upper part of the euphotic zone is established for the offshore Laccadive Sea. Year-round, the pigment content is low and the seasonal range is small, following the pattern of the nutrient-poor Arabian Sea to the west. Apparently, indigenous phytoplankton blooms are absent. July and August, however, were poorly studied because of cloud cover. Interannual differences during the northeast monsoon and the spring intermonsoon periods are minor. The abundant phytoplankton caused by the upwelling off India during the southwest monsoon remains essentially restricted to the shelf, but there are occasional large, zonal outbreaks into the Laccadive Sea, as well as others advected to the south of India. Visual inspection of the raw CZCS scenes for June through November 1982-1985, with almost no data until August or even September, shows such outbreaks of pigment-rich water to be common. Inspection of monthly SeaWiFS images for 1997 through part of 2001 confirms the absence of indigenous phytoplankton blooms.
\end{abstract}

\section{Introduction}

\subsection{Geography, hydrography, and nutrients}

The offshore Laccadive (Lakshadweep) Sea, 1 to $3 \mathrm{~km}$ deep, is bordered by the shelf breaks off India, Sri Lanka, and the island chains on the ChagosLaccadive Ridge to the west (figure 1). Herein, its south-north extent is defined as between 5 and $16^{\circ} \mathrm{N}$, because the coverage by the NIMBUS-7 Coastal Zone Color Scanner (CZCS), our principal data source, was very poor south of this area. Also the waters between Sri Lanka and $79^{\circ} \mathrm{E}$ are neglected. The physical oceanography of the upper layers is affected by the monsoons with their reversing winds, as well as changing cloudiness and pre- cipitation, and is subject to seasonal reversal of surface currents. Vertical stability and mixing also vary seasonally. For our purposes, we divided the year into three periods: the northeast (NE) monsoon, between December and February; a transitional, intermonsoon period from March into June; and the southwest (SW) monsoon, beginning midJune or early July and extending with its biological after-effects through October/November, the so-called post-monsoon time.

During much of the NE monsoon, the surface current sets northward (see references cited below). The upper layers are dominated by low-salinity waters from the Bay of Bengal and equatorial latitudes and, therefore, are stratified more than the Arabian Sea to the west and north so that

Keywords. Laccadive sea; Lakshadweep sea; CZCS; phytoplankton pigment; seasons; 1979-1981. 


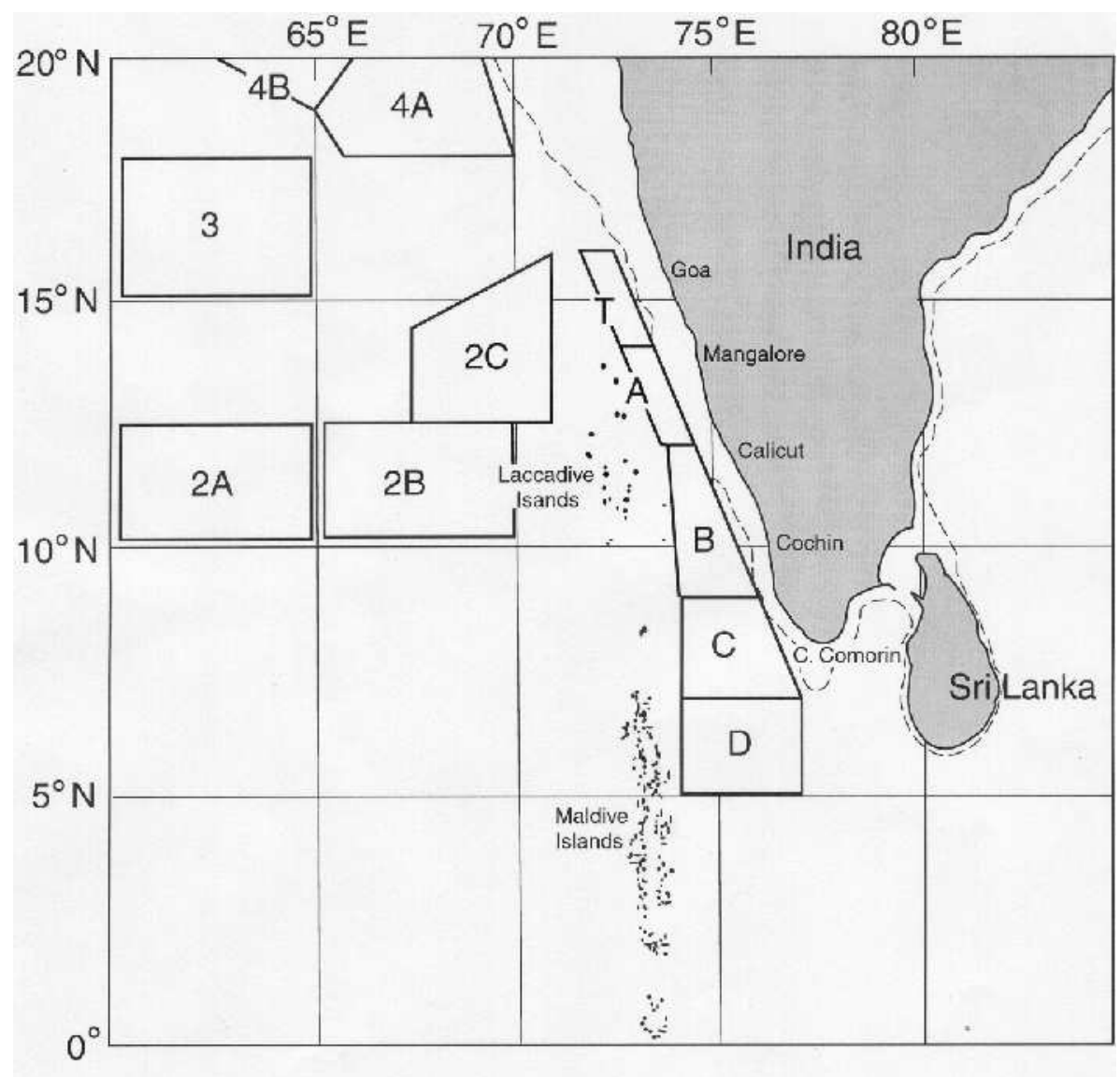

Figure 1. The Laccadive Sea, with observation boxes T, A-D, and areas 2-4 of Banse and English (2000) in the Arabian Sea. Broken line, 200-m isobath.

there is no deep mixed layer. During the intermonsoon period, the current reverses, and the upper layers resemble those of the permanently highsalinity, low-nutrient waters of the open Arabian Sea, including a seasonal thermocline well above the permanent pycnocline. This period brings the highest surface temperature of the year. Upsloping of sub-pycnocline water onto the Indian shelf begins in the south in February or March and, from the onset of the SW monsoon in June, extends for $4-5$ months over the entire continental border of the Laccadive Sea. In places, actual coastal upwelling to the surface leads to extensive phytoplankton blooms. The effects beyond the continental shelf of the upsloping, with the ensuing upward mixing of nutrients, and the upwelling proper has hardly been explored by observations, but is a focus of the present paper: Does the divergence, which causes the upsloping and upwelling, advect enriched water off the shelf, causing high concentrations of phytoplankton and zooplankton in the open Laccadive Sea and to the south of India?

Beyond this general outline, little detail is known about the oceanography of the open Laccadive Sea from in situ observations, especially in respect to seasonal and interannual aspects so salient in a monsoonal climate, or regarding regular northsouth differences. There are some offshore sections by earlier expeditions, mostly during the NE monsoon and the following intermonsoon periods, and, since 1957, many cross-shelf sections that extend slightly beyond the continental slope off India. However, very few cruises covered major parts of the Laccadive Sea at any one time and were published in detail (for physical oceanography, e.g., Shetye et al 1990, 1991). Thus, except for monthly climatologies of currents and surface temperature as in atlases by various hydrographic services, the only areal pictures of seasonality from in situ observations by merchant mariners are the monthly surface maps of temperature by Hastenrath and Lamb (1979) and Rao et al (1989) and of salinity by Hareesh Kumar and Mathew (1997) and Wyrtki (1971; bi-monthly). Colborn (1975) discussed the offshore, climatological thermal structure averaged areally, but he included waters to the west of the Laccadive Islands and east of Sri Lanka in the Laccadive Sea regarding them as distinct from the Arabian Sea. Examples of recent papers with single or few sections extending well beyond the Indian shelf are Varkey et al (1979) and Muraleedharan and Prasanna Kumar (1996), who examined the 
hydrography for three and one cruises, respectively. The semi-annual nutrient maps in Wyrtki (1971), based on sparse data, suggest that the offshore surface layer of the Laccadive Sea is nitrate-depleted year-round (cf. Sen Gupta et al 1980; Singh et al 1990).

Mathematical modeling (McCreary et al 1993; Bruce et al 1994, 1998; Shankar and Shetye 1997; Shankar 1998) points to the role of remote physical forcing, especially from the Bay of Bengal, for the meridional currents in the Laccadive Sea and the upsloping and upwelling on its eastern side. Moreover, zonal dynamic connections extending into and across the Laccadive Sea from west of the island chains are noted, which suggest to us that material zonal nutrient enrichment of the offshore domain is absent. For December to March, Shankar and Shetye (1997) and Bruce et al (1998) modeled an anticyclonic eddy off southwest India and accompanied the calculation by field data (cf. their bi-monthly figures; see also Prasanna Kumar et al 1998). The eddy would not favor nutrient enrichment of the upper layer. Moreover, the upward nutrient flux is depressed during this time by the salinity stratification in the isothermal surface water. Shankar and Shetye (1997) also modeled a cyclonic eddy in the same region as developing early during the SW monsoon.

\subsection{Phytoplankton pigment}

Information on offshore concentrations of chlorophyll from ships is especially scarce, even for the surface. Two summarizing maps for NovemberApril and May-October in Krey and Babenerd (1976) suggest an increase from $0.1 \mathrm{mg} \mathrm{m}^{-3}$ to $0.3 \mathrm{mg} \mathrm{m}^{-3}$ between the first and second periods south of $10^{\circ} \mathrm{N}$. However, only 13 and 6 data points, respectively, of unknown temporal and spatial distribution between 10 and $20^{\circ} \mathrm{N}$, east of $70^{\circ} \mathrm{E}$, were available to Krey and Babenerd (1976; cf. Bhattathiri and Devassy 1979 for March to April). Chlorophyll maps (column values) for the SW monsoon season of 1987 are found in Pant (1992) and Banse et al (1996) and two satellitederived pigment maps, for January and September 1979, in Goes et al (1992). They depict low pigment values off the shelf, except for September 1979 when high chlorophyll clearly extended beyond the shelf south of approximately $12^{\circ} \mathrm{N}$. One east-west section during each of the NE and SW monsoon seasons of 1979 at $15^{\circ} \mathrm{N}$, from the Indian coast to $69^{\circ} \mathrm{E}$ and $67^{\circ} \mathrm{E}$, show $<0.2$ and $<0.1 \mathrm{mg} \mathrm{m}^{-3}$, respectively (Goes et al 1992). On their SW monsoon cruise between $71^{\circ} \mathrm{E}$ and $72^{\circ} \mathrm{E}$, well seaward of the uptilting of isotherms near the shelf break, a pigment front (from $<0.05$ to
$>0.3 \mathrm{mg} \mathrm{m}^{-3}$ chlorophyll), without temperature or nitrate signals, was observed, while chlorophyll values of up to $6 \mathrm{mg} \mathrm{m}^{-3}$ were recorded on the shelf. Other offshore data were collected by Bhargava et al (1978). Maps of mesozooplankton by Silas (1972); Mathew et al (1990), and Madhupratap et al (1992), the latter two with some seasonal interpretations, demonstrate the expected, considerable enrichment toward and on the shelf.

\subsection{Goals of the study}

Ships running sections are not adequate platforms for the collection of synoptic data over large areas because of the confounding of temporal and spatial change during an extended cruise. However, pigment concentration in the upper quarter or third of the euphotic zone can be sensed by satellites, permitting repeated mapping of plant pigment to separate spatial and temporal differences in phytoplankton distributions. Moreover, satellite-derived pigment concentrations tend to be correlated with chlorophyll integrated through the euphotic zone, including the pigment in the Deep Chlorophyll Maximum, if present (e.g., Platt and Herman 1983; Morel and Berthon 1989).

Thus, we wish to identify seasonal and interannual cycles in near-surface phytoplankton pigment concentrations offshore in the Laccadive Sea based on images collected by the CZCS between November 1978 and December 1981. This was the period of best temporal coverage and least concern about sensor degradation (Evans and Gordon 1994). We quantify the temporal (days to years) and spatial (tens to hundreds of kilometers) variability in pigment concentration (chlorophyll $a$, including some phaeopigment) in five offshore areas located between $516^{\circ} \mathrm{N}$ and $71.577^{\circ} \mathrm{E}$ (figure 1). The spatial and temporal patterns are noted as much as those of the concentrations.

Understanding the presence and timing of phytoplankton concentrations is essential in the investigation of other organisms in the food web and of particle fluxes to the deep sea. Further, offshore filaments or plumes of pigment originating from the shelf give hints to hydrographic processes that may remove zooplankton and fish eggs and larvae from the shelf. Finally, pigment observations may serve as checks on model-derived patterns as in McCreary et al (1996).

\section{Methods}

\subsection{General}

For the quantitative study, five boxes labeled $\mathrm{T}$, $\mathrm{A}, \mathrm{B}, \mathrm{C}$, and D were delineated, skirting the shelf 
break to the east and the Laccadive and Maldive Islands to the west between 5 and $16^{\circ} \mathrm{N}$. Each box was arbitrarily limited to two degrees of latitude in north-south extent except Box B (three degrees; figure 1). The southernmost box (D) was to explore an area potentially little influenced by coastal upwelling. Qualitative observations by visual inspection of images were also made to the east of Box D. Individual 2-minute CZCS scenes (Level II, FM4 product (pigment values), Gordon et al 1983, Evans and Gordon 1994) were retrieved from optical disks containing the National Aeronautic and Space Administration's (NASA) Global Data Set (GDS), available from the Goddard Space Flight Center, Greenbelt, MD. These scenes had been subsampled every 4th pixel on every 4th line ("4-km resolution") and processed with standard atmospheric correction algorithms and a default (marine) aerosol correction for openocean atmosphere. Due to the sub-sampling, each pixel represents an area of approximately $16 \mathrm{~km}^{2}$ of ocean surface beneath the satellite. Only scenes obtained with gains of 1 or 2 were included. All scenes available between November 1978 and December 1981 that were visually determined to contain pigment data within at least one of the boxes were used.

In our processing of the satellite measurements, only pixels $<9.0 \mathrm{mg}$ pigment $\mathrm{m}^{-3}$ were considered valid because blooms with higher pigment values are highly unlikely in the open, low-latitude sea. The methods are detailed in an Appendix. Briefly, NASA's default atmospheric correction coefficient (epsilon) was found to be satisfactory and errors from multiple scattering interactions and possible electronic overshoot of the sensor after passing over large, bright clouds were checked for and not found to be material. Therefore, the Level II, FM4 product of the GDS was used as is, thereby including some potentially suspect data but avoiding the loss of many dates especially during the SW monsoon. The mean pigment concentrations for each box were calculated for the pixels not close to clouds as determined subjectively. Medians were also computed, since histograms of processed CZCS scenes are non-Gaussian even after dropping the pigment values $>9 \mathrm{mg} \mathrm{m}^{-3}$. Note that there is no local ground truth available for these years so that the accuracy of the data is not known, but there is no doubt that the spatial and temporal patterns are accurate. Elsewhere, the calculated pigment values are believed to be within $35 \%$ of the true concentrations (cf. Evans and Gordon 1994).

Often, partial coverage of boxes occurred depending upon where the satellite began recording a 2-min scene. Partial scenes for the same day were merged and the pigment means and stan- dard deviations calculated from the combined data. Because the scenes were not remapped (i.e., the foreshortening of the satellite's scenes was not corrected and the images projected on a geographic grid), the total number of pixels within any box varied among dates even in the absence of partial cloud cover. Data for a box were used only if the number of valid pigment pixels was $>1 \%$ of the total pixels in the part of the box within the satellite scan; the criterion applies also to boxes fully scanned on a given day. The end product of this processing is henceforth called an image.

A total of 303, 2-min FM4 scenes were used, retrieved between November 1978 (start of the CZCS transmission) and December 1981and corresponding to 182 days of coverage (cf. figures 3-7). In these figures, the daily means are plotted on logarithmic ordinates to emphasize the trends at low concentrations but compare figures 6 and 7 with the same data plotted on linear ordinates in Fig. 8. Table 1 presents overall means and ranges, as well as some medians.

\subsection{Pigment patterns during the $S W$ monsoon seasons 1982-1985 and 1997-2001}

For a qualitative study of pigment patterns during the SW monsoon seasons of 1982-1985 (here, June through November), the browse files for the individual days in the Global Data Set were inspected (http://daac.gsfc.nasa.gov/CAMPAIGNDOCS/ BRS_SRVR/czcsbrs main.html). These are smallscale Level II (pigment, not remapped) scenes that only permit the recognition of large features. Also, monthly chlorophyll maps of the SeaWiFS (Sea-viewing Wide Field Sensor) from September 1997 through December 2001 were inspected for the same purpose (http://seawifs.gsfc.nasa.gov/SEAWIFS, SeaWiFS homepage, Biosphere, SeaWiFS Level III Standard Mapped Images).

\section{Results}

\subsection{Pigment variability}

Before turning to the seasonal, interannual, and regional trends in figures $3-7$, variability on three time scales will be illustrated so that differences in the panels of these figures are more easily interpreted. CZCS daily images of phytoplankton pigment distribution are shown in color in figure 2 for two days each during the NE monsoon, the intermonsoon, and the SW monsoon.

Figure 2 top row illustrates day-to-day changes of pigment concentration. The two December 1978 
Table 1. Seasonal mean pigment concentrations (FM4, $\mathrm{mgm}^{-3}$; bold) with standard deviations (S.D.) and number of dates and (second rows) range of daily mean pigment concentrations for each box by season and year. Also, range of daily median pigment concentrations (FM4, $\mathrm{mgm}^{-3}$; bold) for July-November. (a) December data from preceding year; (b) no April data; (c) no September data; (d) no August-September data; (e) no July data; (f) no April-May data.

\begin{tabular}{|c|c|c|c|c|c|c|c|c|c|c|}
\hline \multirow[t]{2}{*}{ Box } & \multirow[t]{2}{*}{ Season } & \multicolumn{3}{|c|}{$1979^{\mathrm{ab}}$} & \multicolumn{3}{|c|}{$1980^{\text {ac }}$} & \multicolumn{3}{|c|}{$1981^{\text {ade }}$} \\
\hline & & $\begin{array}{l}\text { Mean } \\
\text { range }\end{array}$ & S.D. & Days & $\begin{array}{l}\text { Mean } \\
\text { range }\end{array}$ & S.D. & Days & $\begin{array}{l}\text { Mean } \\
\text { range }\end{array}$ & S.D. & $\overline{\text { Days }}$ \\
\hline \multirow{4}{*}{$\mathrm{T}$} & Dec - Feb & $\begin{array}{c}\mathbf{0 . 2 0} \\
0.10-0.51\end{array}$ & 0.09 & 26 & $\begin{array}{c}\mathbf{0 . 1 8} \\
0.12-0.29\end{array}$ & 0.04 & 24 & $\begin{array}{c}\mathbf{0 . 1 9} \\
0.11-0.36\end{array}$ & 0.07 & 13 \\
\hline & Mar - June & $\begin{array}{c}\mathbf{0 . 1 3} \\
0.07-0.19\end{array}$ & 0.04 & 10 & $\begin{array}{c}\mathbf{0 . 0 9} \\
0.05-0.11\end{array}$ & 0.02 & 10 & $\begin{array}{c}\mathbf{0 . 1 3} \\
0.07-0.20\end{array}$ & 0.04 & 11 \\
\hline & July - Nov & $\begin{array}{c}\mathbf{0 . 5 4} \\
0.22-1.48^{\mathrm{e}}\end{array}$ & 0.34 & $17^{\mathrm{e}}$ & $\begin{array}{c}\mathbf{0 . 3 1} \\
0.17-0.48^{\mathrm{e}}\end{array}$ & 0.10 & $9^{\mathrm{e}}$ & $\begin{array}{c}\mathbf{0 . 2 2} \\
0.10-0.46\end{array}$ & 0.12 & 10 \\
\hline & Median & $0.20-1.16^{\mathrm{e}}$ & & & $0.15-0.34^{\mathrm{e}}$ & & & $0.09-0.30$ & & \\
\hline \multirow{4}{*}{ A } & Dec - Feb & $\begin{array}{c}\mathbf{0 . 1 5} \\
0.09-0.27\end{array}$ & 0.04 & 23 & $\begin{array}{c}\mathbf{0 . 1 6} \\
0.12-0.21\end{array}$ & 0.03 & 24 & $\begin{array}{c}\mathbf{0 . 1 7} \\
0.11-0.32\end{array}$ & 0.07 & 12 \\
\hline & Mar - June & $\begin{array}{c}\mathbf{0 . 1 1} \\
0.08-0.17\end{array}$ & 0.03 & 11 & $\begin{array}{c}\mathbf{0 . 1 0} \\
0.07-0.13\end{array}$ & 0.02 & 10 & $\begin{array}{c}\mathbf{0 . 1 3} \\
0.08-0.30\end{array}$ & 0.07 & 12 \\
\hline & July - Nov & $\begin{array}{c}\mathbf{0 . 7 4} \\
0.18-2.12^{\mathrm{e}}\end{array}$ & 0.51 & $19^{\mathrm{e}}$ & $\begin{array}{c}\mathbf{0 . 3 7} \\
0.18-0.80^{\mathrm{e}}\end{array}$ & 0.19 & $9^{\mathrm{e}}$ & $\begin{array}{c}\mathbf{0 . 1 7} \\
0.10-0.30\end{array}$ & 0.07 & 9 \\
\hline & Median & $0.13-1.22^{\mathrm{e}}$ & & & $0.17-0.60^{\mathrm{e}}$ & & & $0.09-0.28$ & & \\
\hline \multirow{4}{*}{ B } & Dec - Feb & $\begin{array}{c}\mathbf{0 . 1 3} \\
0.11-0.22\end{array}$ & 0.03 & 15 & $\begin{array}{c}\mathbf{0 . 1 6} \\
0.11-0.19\end{array}$ & 0.03 & 24 & $\begin{array}{c}\mathbf{0 . 1 6} \\
0.10-0.28\end{array}$ & 0.05 & 13 \\
\hline & Mar - June & $\begin{array}{c}\mathbf{0 . 1 3} \\
0.09-0.21\end{array}$ & 0.03 & 9 & $\begin{array}{c}\mathbf{0 . 1 1} \\
0.06-0.13\end{array}$ & 0.02 & 10 & $\begin{array}{c}\mathbf{0 . 1 7} \\
0.08-0.48\end{array}$ & 0.12 & 11 \\
\hline & July - Nov & $\begin{array}{c}\mathbf{0 . 9 3} \\
0.24-3.01^{\mathrm{e}}\end{array}$ & 0.74 & $22^{\mathrm{e}}$ & $\begin{array}{c}\mathbf{0 . 3 5} \\
0.11-0.89\end{array}$ & 0.28 & 11 & $\begin{array}{c}\mathbf{0 . 1 5} \\
0.12-0.20\end{array}$ & 0.02 & 8 \\
\hline & Median & $0.19-2.13^{\mathrm{e}}$ & & & $0.10-0.56$ & & & $0.11-0.20$ & & \\
\hline \multirow{4}{*}{$\mathrm{C}$} & Dec - Feb & $\begin{array}{c}\mathbf{0 . 1 3} \\
0.11-0.17\end{array}$ & 0.03 & 11 & $\begin{array}{c}\mathbf{0 . 1 5} \\
0.10-0.22\end{array}$ & 0.04 & 22 & $\begin{array}{c}\mathbf{0 . 1 9} \\
0.12-0.30^{\mathrm{f}}\end{array}$ & 0.07 & $9^{\mathrm{f}}$ \\
\hline & Mar - June & $\begin{array}{c}\mathbf{0 . 1 0} \\
0.07-0.18\end{array}$ & 0.03 & 11 & $\begin{array}{c}\mathbf{0 . 0 9} \\
0.06-0.12\end{array}$ & 0.02 & 10 & $\begin{array}{c}\mathbf{0 . 1 5} \\
0.07-0.27\end{array}$ & 0.07 & 10 \\
\hline & July - Nov & $\begin{array}{c}\mathbf{0 . 6 0} \\
0.12-1.87^{\mathrm{e}}\end{array}$ & 0.52 & $21^{\mathrm{e}}$ & $\begin{array}{c}\mathbf{0 . 2 2} \\
0.10-0.44^{\mathrm{d}}\end{array}$ & 0.12 & $8^{\mathrm{d}}$ & $\begin{array}{c}\mathbf{0 . 2 6} \\
0.15-0.44\end{array}$ & 0.16 & 3 \\
\hline & Median & $0.11-0.83^{\mathrm{e}}$ & & & $0.08-0.35^{\mathrm{d}}$ & & & $0.14-0.34$ & & \\
\hline \multirow{4}{*}{$\mathrm{D}$} & Dec - Feb & No data & & & $\begin{array}{c}\mathbf{0 . 1 6} \\
0.10-0.24\end{array}$ & 0.05 & 15 & $\begin{array}{c}\mathbf{0 . 1 8} \\
0.11-0.29\end{array}$ & 0.07 & 8 \\
\hline & Mar - June & $\begin{array}{c}\mathbf{0 . 0 9} \\
0.06-0.15\end{array}$ & 0.02 & 13 & $\begin{array}{c}\mathbf{0 . 0 8} \\
0.06-0.11\end{array}$ & 0.02 & 7 & $\begin{array}{c}\mathbf{0 . 1 7} \\
0.08-0.30^{\mathrm{f}}\end{array}$ & 0.09 & $6^{\mathrm{f}}$ \\
\hline & July - Nov & $\begin{array}{c}\mathbf{0 . 2 0} \\
0.09-0.31\end{array}$ & 0.06 & 16 & $\begin{array}{c}\mathbf{0 . 1 6} \\
0.07-0.27^{\mathrm{d}}\end{array}$ & 0.08 & $7^{\mathrm{d}}$ & $\begin{array}{c}\mathbf{0 . 1 7} \\
0.16-0.19\end{array}$ & 0.02 & 2 \\
\hline & Median & $0.08-0.28$ & & & $0.06-0.28^{\mathrm{d}}$ & & & $0.15,0.15$ & & \\
\hline
\end{tabular}

dates are quite atypical for the season, because a plume is running along the western edge and across to the west of the northernmost Box T. The feature remained intact and in place on the second day, i.e., the current was not fast enough to cause much translation. The concentrations in the triangular core, however, had increased, as well as at the eastern edge of Box A, which may well have been due to phytoplankton growth. Virtually no change in mean pigment $\left(0.01 \mathrm{mg} \mathrm{m}^{-3}\right)$ occurred in most of Box A and all of Box B. The relatively high standard deviations (S.D.) during both days in boxes $\mathrm{T}$ 
and A (figures 3 and 4 ) reflect the presence of water with markedly different pigment content, in contrast to Box B (figure 5). On 21st November 1978, a similar feature as in figure 2 top was present in Box A, but it is not known whether it was caused by the same advective event as the plume of early December.

Another example of low day-to-day variability is 8th June (figure 2, middle row, right) and 9th June 1979 (not shown). The change in mean pigment concentration between these two days for boxes $\mathrm{T}, \mathrm{A}, \mathrm{B}$, and $\mathrm{D}$ was only $0.01 \mathrm{mg} \mathrm{m}^{-3}$ while in Box $\mathrm{C}$ it was $0.03 \mathrm{mg} \mathrm{m}^{-3}$. Mean pigment was low for all boxes $\left(0.06\right.$ to $\left.0.13 \mathrm{mg} \mathrm{m}^{-3}\right)$. This low day-to-day variability is the rule for the NE monsoon and intermonsoon periods for the boxes along the Indian shelf, and for the almost oceanic Box $\mathrm{D}$ even during much of the SW monsoon. Note that marked date-to-date changes of means as in figures 3-7 during the two quiet periods of the year may not have been caused by local growth or decay, but may have been artifacts due to the satellite having viewed different parts of our very large boxes (e.g., figure 2, Box B on 18th October 1979).

Two images four days apart during October 1979 (figure 2, bottom row) illustrate short-term variation of pigment distribution on an about weekly scale during a season when the coastal current tends to be strong. On 14th October, the area between the coast of India and the east edges of the boxes contained high levels of pigment. This chlorophyll-rich water spreading seaward affected all boxes. High pigment crossed the eastern edge of the northern Box $\mathrm{T}$ while in the adjoining Box $\mathrm{A}$ the pigment extended southwest across the box and to the west. (Possibly, an independent eddy was present west of the box.) The mean pigment concentration was $0.63 \mathrm{mg} \mathrm{m}^{-3}$ for both boxes $\mathrm{T}$ and A. In Box B, a broad plume stretched from the coast across the box and far beyond the Laccadive Islands. The mean pigment concentration for Box B was $1.02 \mathrm{mg} \mathrm{m}^{-3}$ with, obviously, a very high S.D. (figure 5). Boxes $\mathrm{C}$ and $\mathrm{D}$ also contained "oceanic" water (dark blue and purple false colors), and high pigment spread only across the eastern edge of Box $\mathrm{C}$ or just into the northeast corner of the southernmost Box D.
Four days later on 18th October, the extent of the high pigment to the east of boxes $\mathrm{T}, \mathrm{A}$, and $\mathrm{B}$ covered the entire coastal area and extended into boxes A and B. Note that over four days, the location of the principal features of the plume in Box B and west of it had essentially not changed, although the pigment concentrations had declined offshore and those along the eastern edges of boxes A and B had increased. The mean pigment concentrations in boxes $\mathrm{T}, \mathrm{C}$, and $\mathrm{D}$ were slightly lower than on 14th October while in Box A the mean had almost doubled to $1.07 \mathrm{mg} \mathrm{m}^{-3}$. The mean in Box B grew only by $0.08 \mathrm{mg} \mathrm{m}^{-3}$.

Six days later on 24th October (image not shown), the chlorophyll-rich area east of the boxes lay close to the coast except for Box $\mathrm{T}$, where it crossed into the box. For the part of this box not covered by clouds, the pigment mean had tripled from the previous week but in boxes A and B the means had decreased by one-half (cf. figures 4 and 5). These pictures again emphasize that at times, means as in figures 3-7 do not reflect the true situation and may hide the occurrence of true blooms that are of $1-200 \mathrm{~km}$ diameter.

Finally, figure 2 middle row, portrays images 2 $1 / 2$ months apart, in order to illustrate that during the intermonsoon, north of the southern tip of India (where early upsloping or upwelling may occur), the pigment is very low over the entire open Laccadive Sea. (Note that the lower limit of the CZCS is $0.04 \mathrm{mg} \mathrm{m}^{-3}$ pigment.) The cause of the pronounced bloom in March 1979 north of about $15^{\circ} \mathrm{N}$ is unknown. To the northwest in the open sea (Area 4a in Banse and English 2000; for location, see figure 1 herein), a bloom was not observed during this year, but during the life time of the CZCS (late 1978 to mid-1986), three dates with moderate pigment means $\left(>0.8 \mathrm{mg} \mathrm{m}^{-3}\right)$ but high S.D. occurred in the first half of March 1984.

Incidentally, in figure 2 bottom row, the atolls of the northern Maldives to the west of Box D (cf. figure 1) are seen as surrounded by high pigment, but it is not clear what the cause of the extension of pigment to the north, paralleling the edge of Box $\mathrm{C}$, might have been. This entire extension was eliminated as questionable in the DM4 product (see Appendix), as was almost all of Box $\mathrm{C}$ and the waters on the shelf to the east.

\section{Figure 2 caption}

Figure 2. CZCS images (FM4) for indicated dates with outlines of boxes. Top row, for 2 successive days during the NE monsoon; the band of pigment advected into the Arabian Sea is extraordinary for this period. Middle row, images separated by 4 days during the SW monsoon, with coastal upwelling and offshore advection. Bottom row, images separated by about $21 / 2$ months during the intermonsoon period. White, clouds (except along the coastline). The very high pigment in the thin line along the coast is almost certainly not representative because of interference of suspended sediment or remnants of colored river water. 

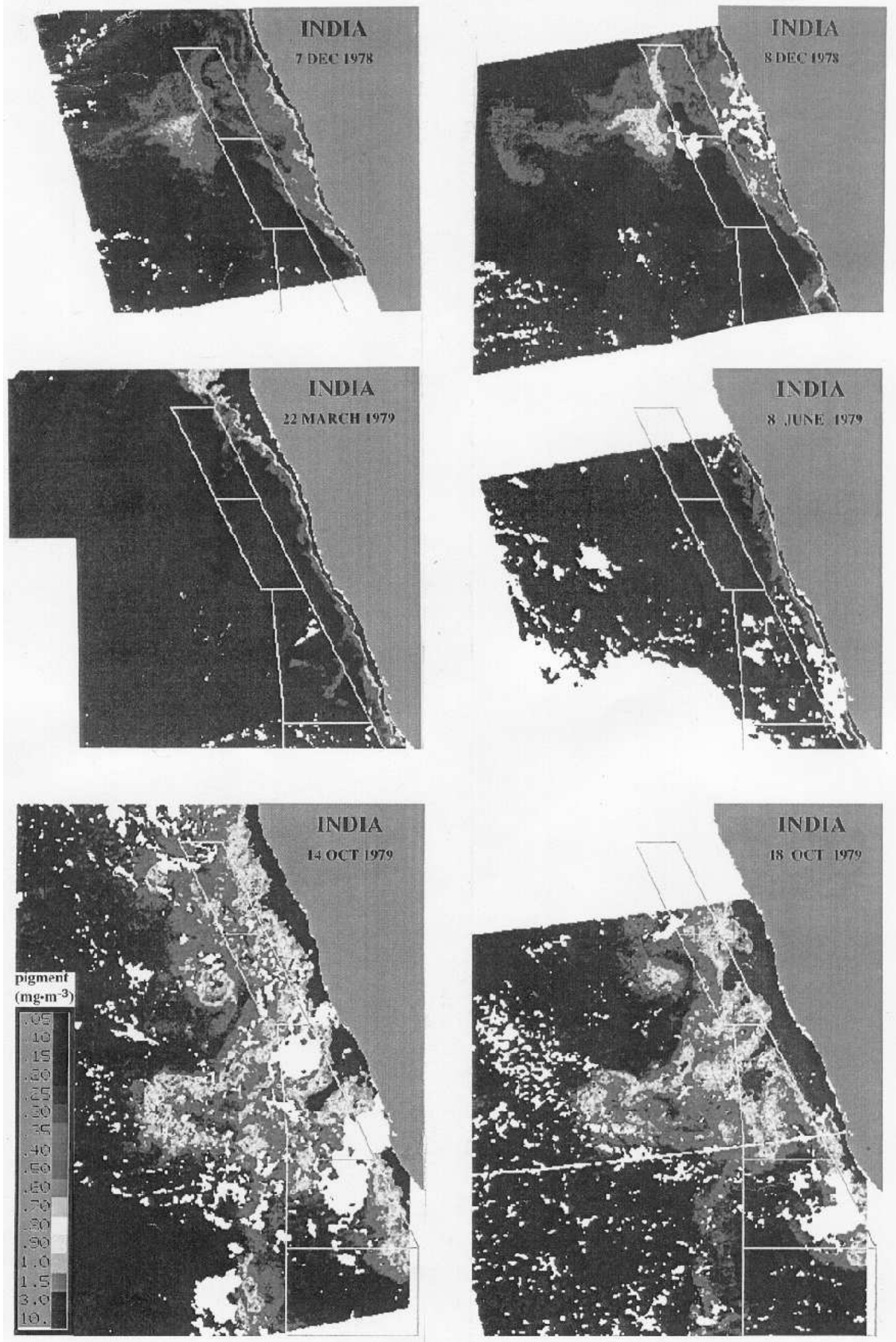

Figure 2. 
3.2 Seasonal, interannual, and regional trends

Daily mean pigment data by year within each box are shown in figures 3-7. For each box by year, Table 1 lists the seasonal means with standard deviations from averaging the daily means as in figures $3-7$, the seasonal range of daily mean concentrations, and for July to November the range of median concentrations. Below, the statistical com- parisons are reviewed; for details, see Lierheimer (1997).

A seasonal pattern of pigment concentrations is evident in all boxes although the signal was small during 1981 (cf. table 1). The values during the NE monsoon and especially during the intermonsoon periods are very low. During these two periods, small variability within days (see the S.D. in figures 3-7), between days (figure 8), and within
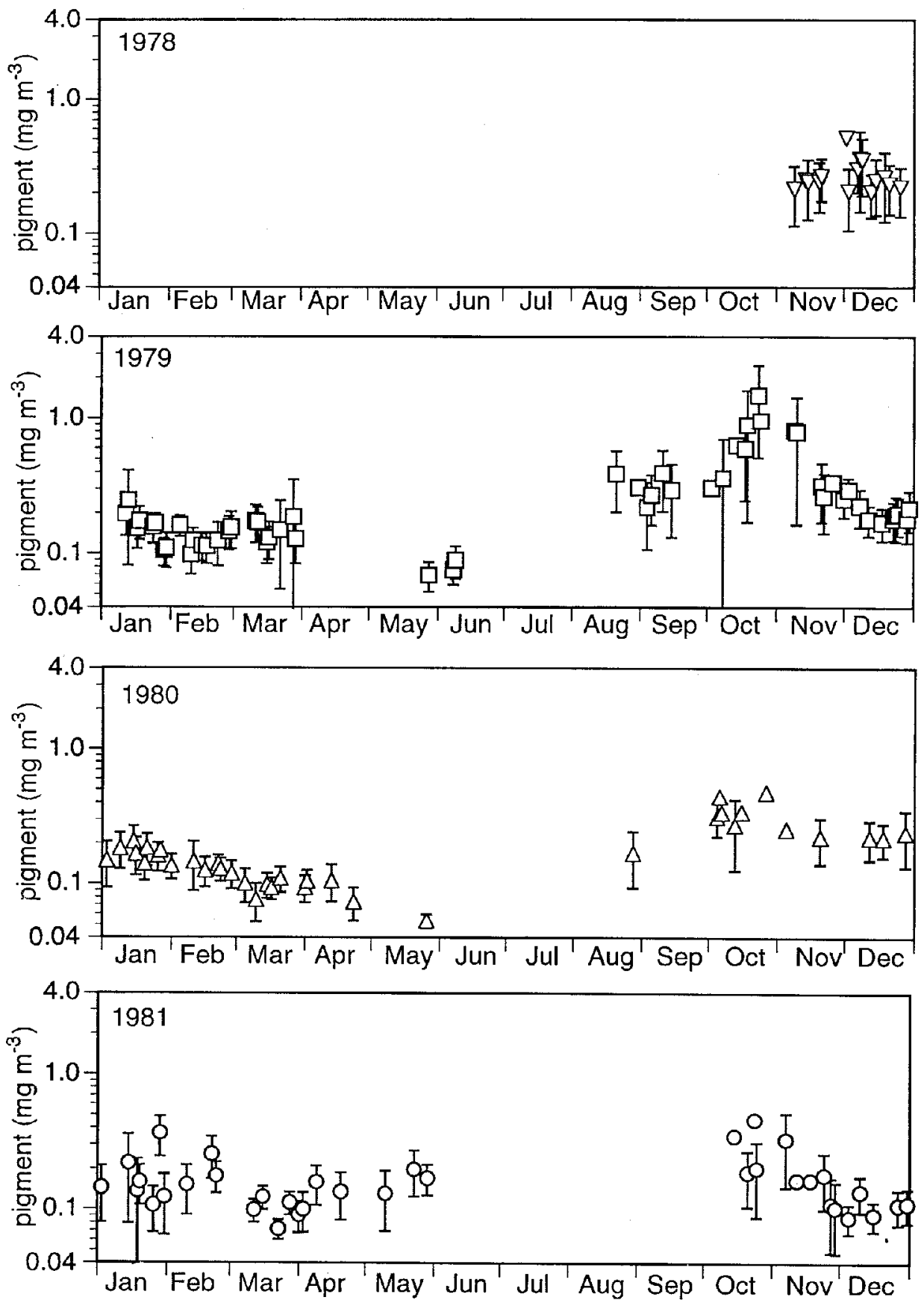

Figure 3. Daily means of phytoplankton pigment (FM4) by year in Box T from November 1978 through December 1981. Note the logarithmic ordinate. Bars, one standard deviation (S.D.). In symbols with no bars, the S.D. was smaller than the height of the symbols (normally, only at low pigment values) or was omitted when it was larger than the mean (normally, only at high pigment values). 

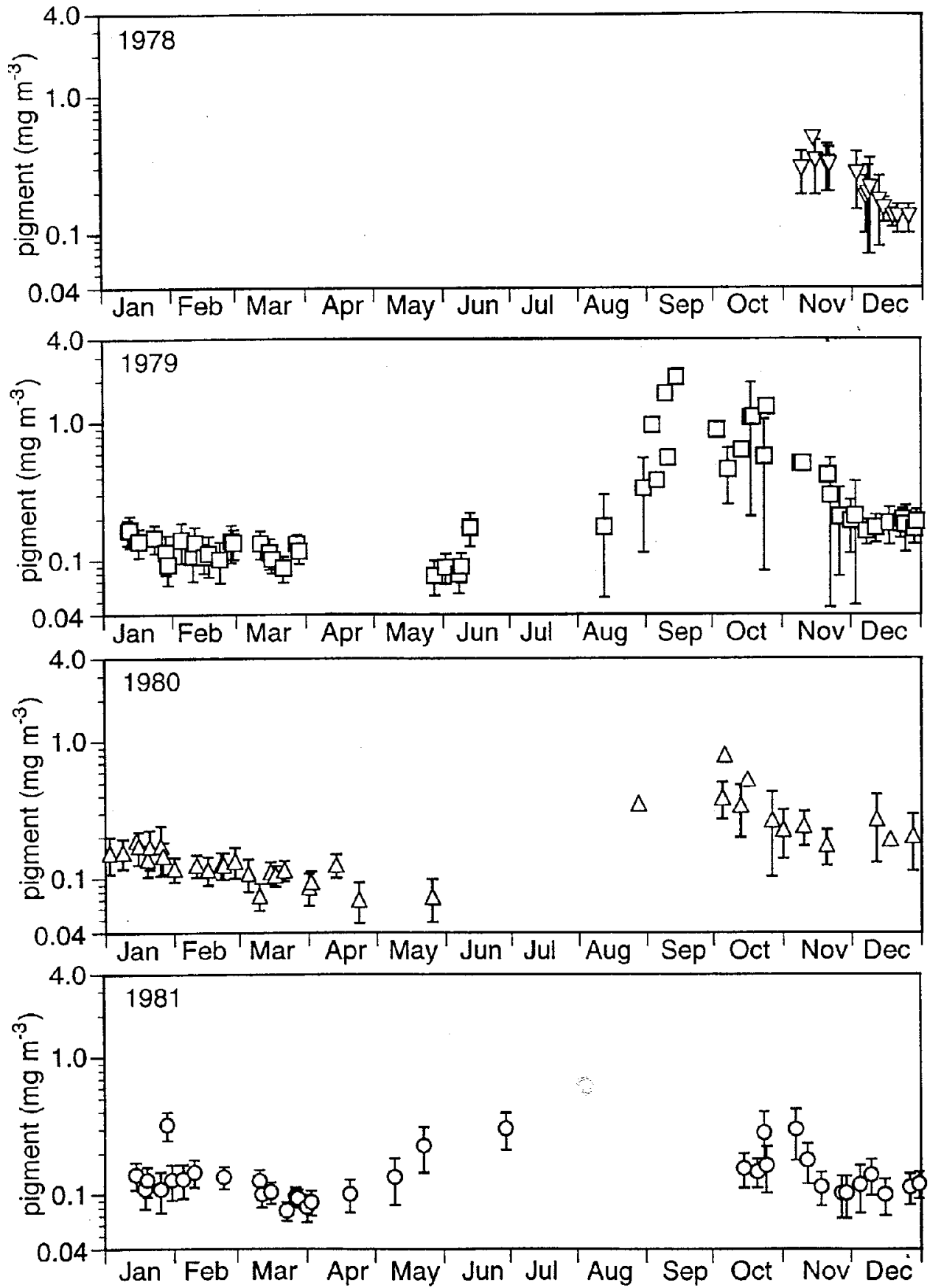

Figure 4. Daily means of phytoplankton pigment (FM4) by year in Box A from November 1978 through December 1981 (see also figure 3).

seasons (table 1) predominates. A pigment decline is marked in all boxes by February, although less so during 1979, followed during May or June by a return to the January level (insufficient data for Box T). In fact, the intermonsoon season differs significantly from the NE monsoon season seven times out of 11 (years $\times$ boxes); boxes $\mathrm{T}-\mathrm{C}$ during 1979 were the exceptions. Interannual differences within boxes during the two periods were not significant except during 1980 and 1981 in Box D.

High mean pigment concentrations dominate during the SW monsoon, with the highest concen- trations recorded in 1979 for all boxes except Box D. Large day-to-day differences are apparent, as is spatial variability within days, often even from pixel to pixel, i.e., on the 4 -km scale. In figures $3-7$, the large changes of box means from day to day are most likely due to different parts of the boxes having been viewed by the CZCS, rather than to actual, dramatic growth or decay of phytoplankton within a particular water body. The SW monsoon periods usually differed significantly from the two other seasons (SW-NE; SW-IM [intermonsoon]), except for SW-NE in 1980 for boxes B and 

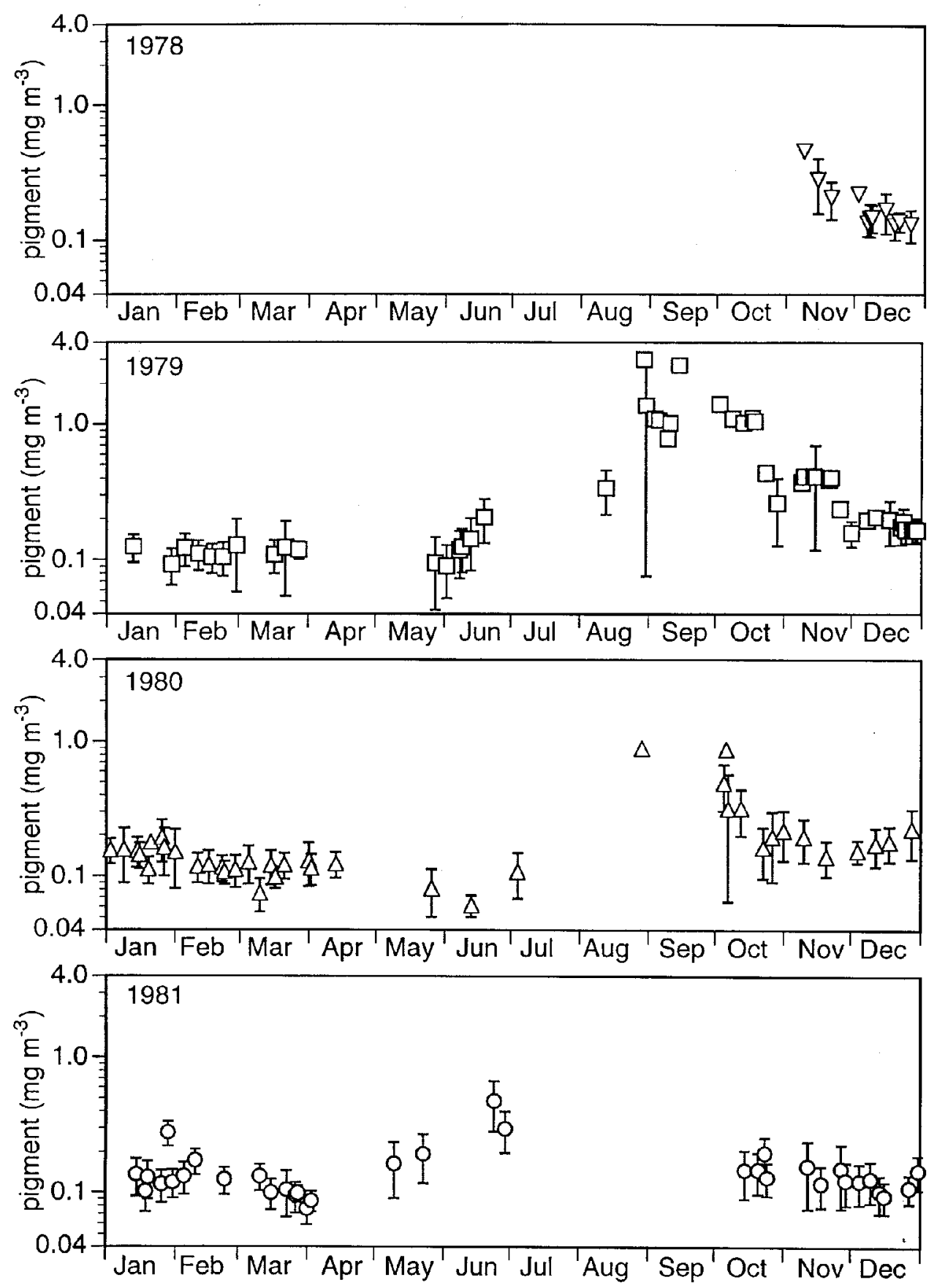

Figure 5. Daily means of phytoplankton pigment (FM4) by year in Box B from November 1978 through December 1981 (see also figure 3).

$\mathrm{D}$ and in 1981 for boxes $\mathrm{T}$ and $\mathrm{A}$ (no data for $\mathrm{C}$ and D).

Visual inspection for the SW monsoon showed that normally, high pigment did not occur throughout any of the boxes, but was restricted to coastal intrusions on the eastern edges or large lobes or streamers of pigment-rich water crossing a box while being surrounded by pigment-poor water (see section 3.4.2). The general spatial variability within dates in boxes $\mathrm{T}-\mathrm{C}$ during the $\mathrm{SW}$ monsoon (cf. figure 2 for two dates) is reflected by the large S.D. in figures $3-6$ and table 1 , as well as by the large differences in the table between the means and the medians at the high end of the ranges during this season. In all boxes during the two other seasons, means and medians of pigment differed only by a few digits in the second decimal place (not shown in table 1; the exception is Box T for December 1978-February 1979, the highest mean and median being 0.51 and $0.33 \mathrm{mg} \mathrm{m}^{-3}$, respec- 

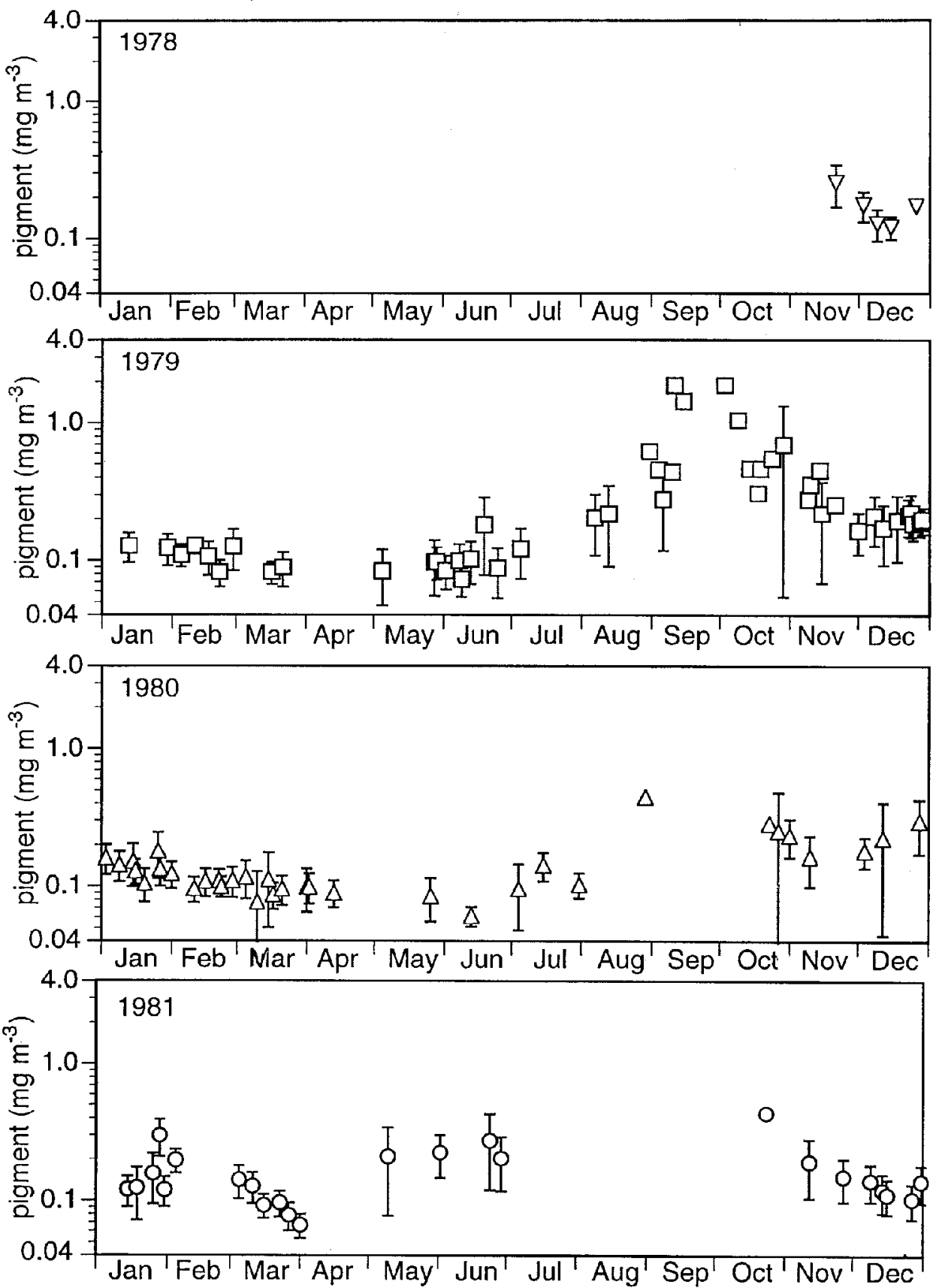

Figure 6. Daily means of phytoplankton pigment (FM4) by year in Box C from November 1978 through December 1981 (see also figure 3 ).

tively). Large differences, with the mean higher than the median, are caused by relatively fewer pixels but with high concentrations ("blooms", if the pixel were in groups) being juxtaposed to more of the low-value pixels.

\subsection{Trends among boxes}

Box D in the south exhibits the smallest change in the seasonal means (table 1). Generally, the S.D. for the daily means during the SW monsoon are lower than in the other boxes (figure 7), but those boxes are similar to each other across nine degrees of latitude. There are some trends, e.g., the seasonal means of the NE monsoon clearly decrease from Box T to Box C in 1979 and 1980, but not in 1981. There is no trend during the intermonsoon periods of 1979 and 1980, but a south-north gradient is present in 1981. In view of the sparse coverage in most scenes from the SW monsoon, as well as the large S.D. (figures 3-7), it is not meaningful to note trends for this season. It may be of future 


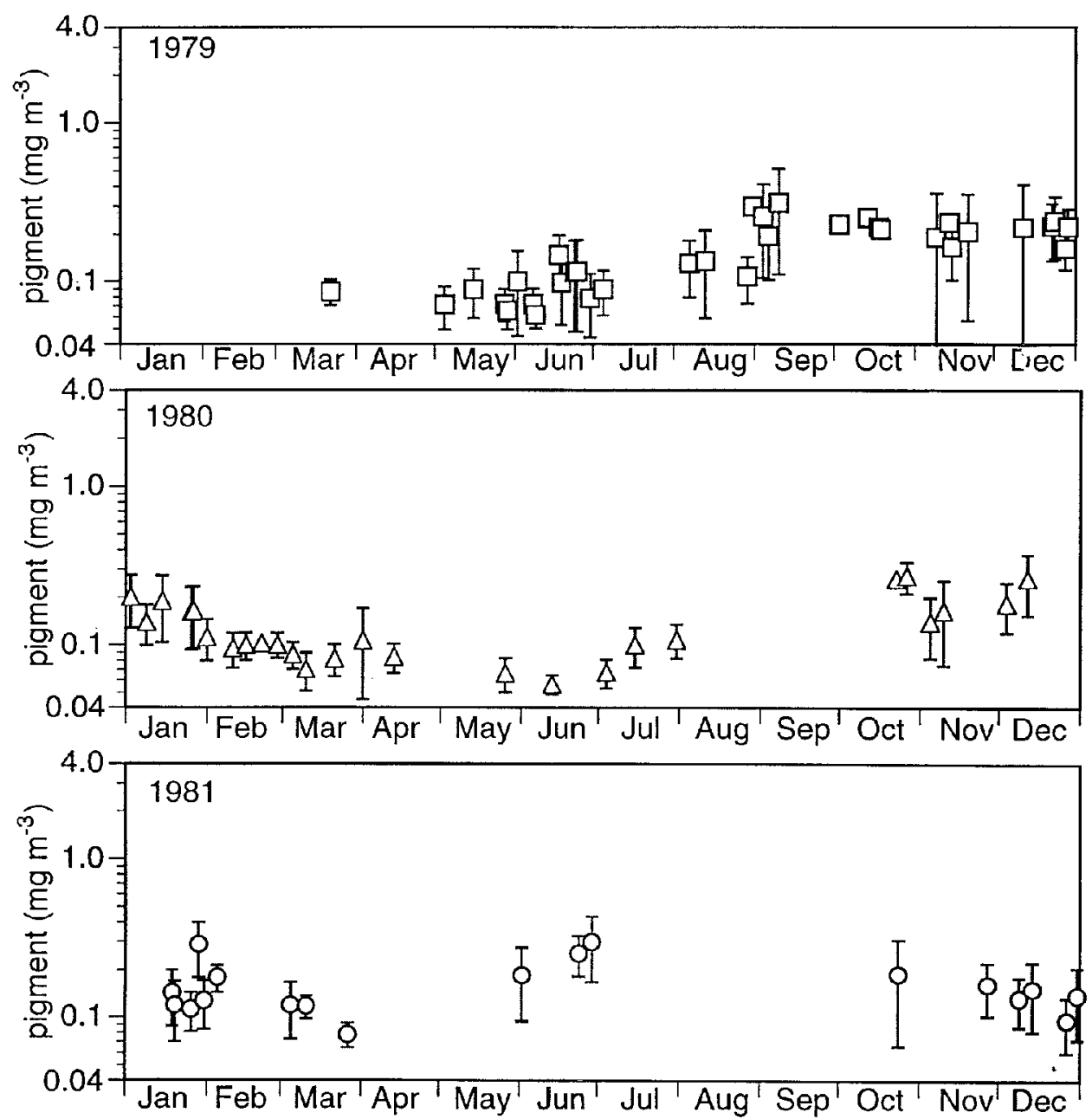

Figure 7. Daily means of phytoplankton pigment (FM4) by year in Box D from March 1979 through December 1981 (see also figure 3).

interest that during 1981, the year with the low pigment values during the SW monsoon, the seasonal means of the preceding period were higher than in the other years. Overall, little can be made of the differences in means in table 1 , in part because of presumably genuine similarity, in part because the true features of pigment distributions that might be understood from the underlying processes have been averaged out. A description of some of these features follows.

\subsection{Visual inspection of images}

\subsubsection{Overview}

A ship at sea or a theoretically inclined researcher looking for cause and effect are not facing means with S.D. as in figures 3-7, but pigment patterns changing in space over several tens of kilometers or less, and also in time over periods of several days or a few weeks. These changes may, for example, represent blooms generated in place or betray water movements. However, viewed in individual satellite images, such features are difficult to quantify. Here, the pigment features in the open sea, especially within the boxes, are classified into three groups based on inspection of images with high S.D. Pigment patterns were classified as "coastal," if high pigment touched the edge or extended from the shelf partly into a box or crossed it as a plume; as "independent," if no sign of coastal influence was observed; or as "questionable," if the cause was unclear due to clouds or only partial coverage of a box. Also, conspicuous features, e.g., plumes originating on the shelf, were noted.

During the NE monsoon, high-pigment patterns were seen in the boxes on eight days. Three of these (one each in 1979, 1980, and 1981) were classified as "coastal," while the patterns on five days (one in 1979 and four in 1980) were "questionable" due to cloud cover. No days during the intermonsoon period showed high standard deviations. During the SW monsoon, 23 days in 1979, eight in 1980, and only two during 1981 contained boxes with 

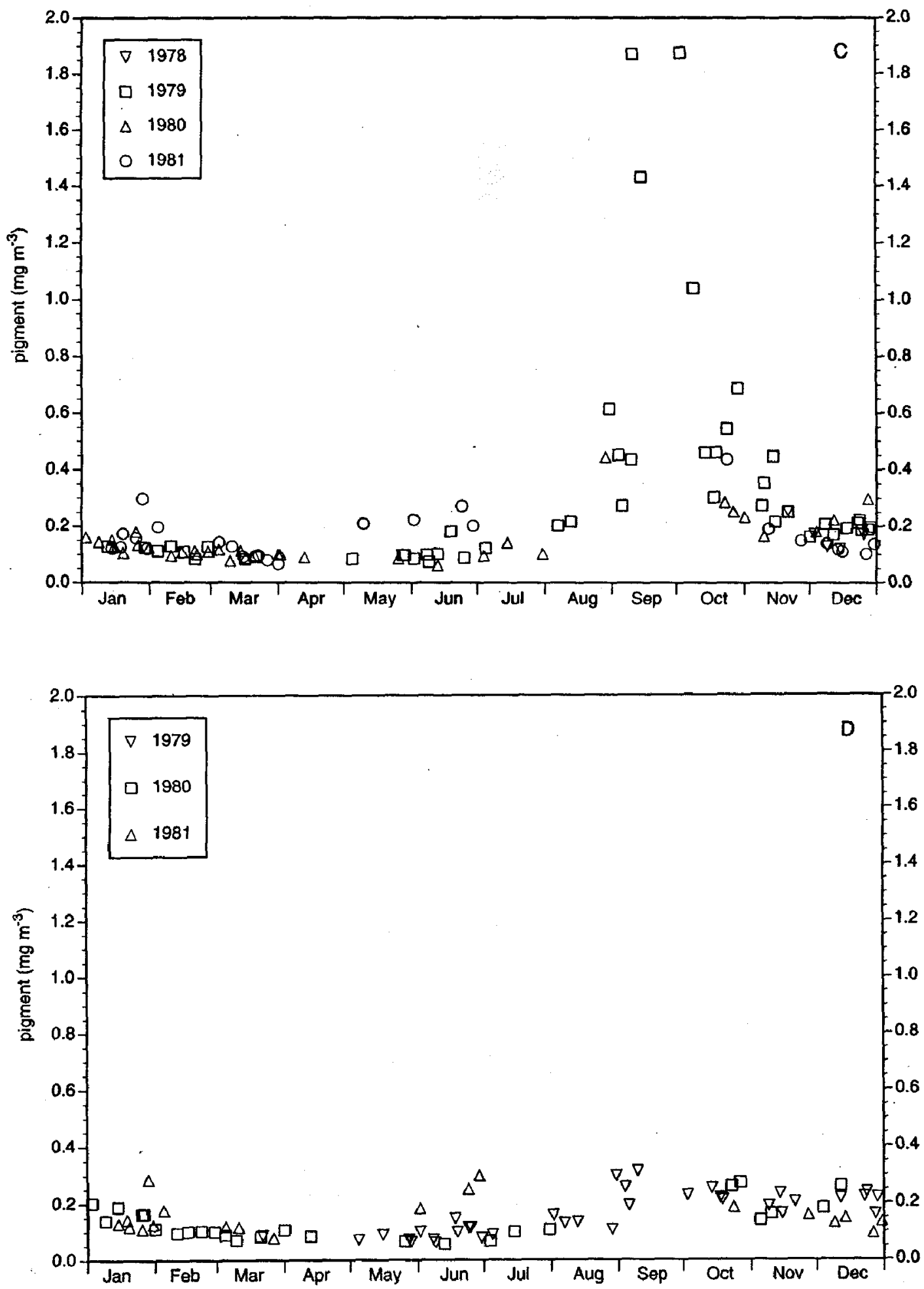

Figure 8. Daily means of phytoplankton pigment (FM4) for all years in Box C (top) and Box D (bottom). Note the linear ordinate and the changed symbols.

large S.D. in the pigment means. In 1979, 17 out of the 23 days comprised boxes with pigment accumulations recognized as "coastal" and nine had at least one box labeled as "questionable." Boxes in seven out of the eight days during 1980 were classified as having "coastal" pigment, with one of these days also containing a "questionable" result. Only one day was categorized as "independent." In 1981, two days were classified as "coastal." These results are prima facie evidence for the 
absence of indigenous blooms in the open Laccadive Sea.

\subsubsection{Outlines of advective features during 1978-1981}

Based on the visual inspection of images as in the preceding section, this section emphasizes the shape and occurrence of high-pigment water during the SW monsoon season, which is considered as being advected after having been generated on the shelf. Advection, instead of massive in situ (offshore) growth of phytoplankton, is inferred from the shapes of the pigment distributions in the form of filaments or, usually, plumes. The pigment distribution is thus used as a near-passive tracer for water movement, in view of the time scale of advection being similar to, or perhaps shorter than, that of the growth and decay of phytoplankton blooms. While the CZCS-derived pigment nearshore should not be regarded as accurate because of interference by suspended sediment or colored dissolved material ("Case 2 water" in the CZCS literature), the mixed signal due to pigment and the interference are carried together by the water. Because the smallest unit of the images (pixel) is $4 \mathrm{~km}$ wide, features $<20 \mathrm{~km}$ on the side were usually overlooked. The length measures below are very rough estimates. Note that the inspected images were not randomly chosen, and the temporal sampling pattern is irregular (see figures 3-7), so that quantification, e.g., for the frequency or timing of advective events, should not be attempted from this overview. Seasons other than the SW monsoon will be mentioned, but latitudes north of $16-17^{\circ} \mathrm{N}$ will not be considered.

October, 1979, as in figure 2 illustrates particularly large advective features for the late SW monsoon when images became available. Most of the shelf (i.e., the area east of the boxes) is occupied by high-pigment water $\left(>3 \mathrm{mg} \mathrm{m}^{-3}\right.$; false red color in figure 2). Sometimes, the pigment-rich water touches the eastern edge of the boxes. By and large, however, the fertilization by upsloping or upwelling is contained to the shelf, and often only to the midand inner shelf. Clearly, there are temporal and also spatial differences on the shelf, including intrusions of near-oceanic $\left(<0.5 \mathrm{mg} \mathrm{m}^{-3}\right)$ water extending $50-100 \mathrm{~km}$ in the north-south direction. These are not discussed further.

The dates for boxes $\mathrm{T}-\mathrm{C}$ in figures 3-7 with high S.D. and often, markedly elevated pigment means result either from broad (100-200 km) marginal intrusions at the edges of the boxes (as in Box A, 8th December 1978, figure 2), or much narrower outbreaks of similarly rich "red" water $\left(>3 \mathrm{mg} \mathrm{m}^{-3}\right)$ into or across the boxes that other- wise appear to the CZCS as poor in phytoplankton. For the outbreaks, relatively wide lobes as in figure 2 for October 1979 or narrow bands (<50 km; not shown) are the rule.

Filaments, i.e., narrow bands of pigment (squirts), were seen occasionally. Prior to the SW monsoon of 1980 , a narrow $(<50 \mathrm{~km}$ wide) filament of coastal "green" water $\left(0.4-0.7 \mathrm{mg} \mathrm{m}^{-3}\right.$, green hues as in figure 2) was seen on 1st April north of Box T to extend about $200 \mathrm{~km}$ from the shore. Similar features were present on 2nd and 13th April 1980 near Goa. The data of 6 th and 7 th October 1980 with high S.D. in boxes A and B were caused by narrow $(<50 \mathrm{~km})$ filaments of $>3 \mathrm{mg} \mathrm{m}^{-3}$ water crossing the boxes, in part passing through oceanic water $\left(0.3-0.5 \mathrm{mg} \mathrm{m}^{-3}\right.$ pigment), and extending about $100 \mathrm{~km}$ beyond the western borders of the boxes. On 2nd November of the same year, two $50-\mathrm{km}$ wide filaments with $>3 \mathrm{mg} \mathrm{m}^{-3}$ pigment were noticed north of Box $\mathrm{T}$ reaching to about $250 \mathrm{~km}$ from the shore and giving rise to one wide plume of $0.4-0.8 \mathrm{mg} \mathrm{m}^{-3}$ pigment that stretched zonally far into the Arabian Sea. Finally noted, especially in October/November 1980 and October 1981, was the wavy seaward edge of the high pigment water $\left(>3 \mathrm{mg} \mathrm{m}^{-3}\right)$ on the shelf. The waves were not sinoid but crested with an approximate wave length and amplitude of $100 \mathrm{~km}$ and $<50 \mathrm{~km}$, respectively. We believe that all of these features are caused by advection, similarly as observed off Oman during the periods of currents moving with the coast on their left side.

Figures 3-6 and table 1, as well as the visual inspection of the actual images, indicate that the SW monsoon season of 1979 differed from those of 1980 and 1981 by high-pigment water from the shelf extending more frequently into the offshore Laccadive Sea. In consequence, higher average pigment content was seen in boxes $\mathrm{T}$ and $\mathrm{A}-\mathrm{C}$ during 1979 than in the other two years. The outbreaks will advect freshwater surplus (from precipitation at sea plus river runoff $>$ evaporation), nutrients, and organic matter including fish eggs and larvae into offshore regions. Did 1979 or 1980-1981 represent the rule?

Summarizing sections 3.4.1 and 3.4.2, the occurrence of high pigment in the interior of boxes $\mathrm{T}-\mathrm{C}$, i.e., the open Laccadive Sea, seems to be restricted to the SW monsoon season, as far as that season could be viewed by the CZCS. Even then, the pigment (and by implication, the water and the nutrients) normally appeared to be advected from the shelf, rather than represent indigenous, open-sea blooms. Shelf-edge blooms (from shelfedge upwelling), separated from high phytoplankton close to the shore by more clear water, or blooms in an eddy-like feature not connected with the shelf, were not observed. The caveat about the 
above is the unsatisfactory or absent coverage for the first two months of the SW monsoon.

The monthly climatological summaries of the SeaWiFS observations show fairly high pigment concentrations over the entire Laccadive Sea mainly during the SW monsoon. The inspection of individual years, however, demonstrates that the normal state is a very low chlorophyll level with the exception of some lobes or plumes that, when superimposed by the climatological averaging, simulate a fertile offshore sea.

\subsubsection{The area east of Box D}

When there is upsloping onto the Indian shelf or actual coastal upwelling, does the displaced surface water move away more or less zonally in plumes or along front-like features to the offshore, as we assumed initially, or may it also be transported parallel to the continent in the mean current and discharged south into the open sea upon reaching the tip of India? A mistake in the initial design of our study was to overlook the latter possibility and not to quantify the CZCS observations to the east of Box D. Therefore, after the termination of the data processing, the images for the SW monsoon season and some adjoining dates of 1978 (November only)-1981 were once more visually inspected for elevated pigment east of Box D. From 5th May to 21st November 1979, 1st April to 20th November 1980, and 10th May to 25th October 1981, 32,18 and 13 images, respectively, were viewed and the color patterns determined without comparing them rigorously with the color bar (cf. figure 2).

From early May through mid-June 1979, the area east of Box D exhibited oceanic pigment levels (approximately $<0.2$ to $0.3 \mathrm{mg} \mathrm{m}^{-3}$ ) although by 16th May there was upwelling off SW India $\left(>3 \mathrm{mg} \mathrm{m} \mathrm{m}^{-3}\right.$ pigment; red color as in figure 2) and subsequently, "green" (false color) water with $0.4-0.7 \mathrm{mg} \mathrm{m}^{-3}$ of pigment covered the southwest Indian shelf. From 18th to 30th June, the pigment was enhanced ("green") but there was oceanic water toward Sri Lanka so that the cause was likely to be on the Indian shelf. From 2nd July through 2nd August, the area east of Box D was again at oceanic pigment levels. On 7th August, a roughly circular field of pigment, up to $0.8-0.9 \mathrm{mg} \mathrm{m}^{-3}$ and of $100-150 \mathrm{~km}$ diameter, just touched the eastern edge of Box D. The field was not bordered by a color front as is often the case with cyclonic eddies that had been nutrient-enriched. On 13th August, a broad band of such "green-yellow" water stretched to Sri Lanka, and on 30-31 August, the entire area between the tip of India and about $6^{\circ} \mathrm{N}$, east of Box D, was filled with "green" water; between the Indian coast and the eastern parts of boxes $\mathrm{B}$ and $\mathrm{C}$, water with $>3 \mathrm{mg} \mathrm{m}^{-3}$ pigment prevailed (cf. the high S.D. in figures 5 and $6)$. On 3rd October (no earlier observations) the field between the tip of India, the coast of Sri Lanka, and the middle of the eastern edge of Box D was covered with water of $>3 \mathrm{mg} \mathrm{m}^{-3}$ pigment. By 14th and 18th October, however, the concentration between Box D and Sri Lanka was $<0.8 \mathrm{mg} \mathrm{m}^{-3}$ (cf. figure 2). On 19th October, the enriched water in a small part of the area was disconnected from the coast, but contiguous with that in Box D. During this month, the borders between oceanic and enriched water were noticeably sharp and straight, extending well beyond $100 \mathrm{~km}$. By 9 th November, there was only oceanic water east of Box D.

In 1980, no enhanced pigment was observed east of Box D between 26th May and 23rd October (see the scant data for Box D, figure 7). On 23rd and 27th October, water of 0.51.0 (or 1.5 ) $\mathrm{mg} \mathrm{m}^{-3}$ pigment, extending from the Indian coast, filled the area in question. It was clearly separated from Sri Lanka by oceanic water.

On 2nd June 1981, Box D was filled with water of about $0.5 \mathrm{mg} \mathrm{m}^{-3}$ pigment, while "green" water to the east was probably connected with the Indian coast. On 24th June, the field east of the largely oceanic Box D was covered with water of $0.4-$ 0.7 as well as $>3 \mathrm{mg} \mathrm{m}^{-3}$ pigment clearly connected to the upwelling along the south and southwest Indian coast but separated from Sri Lanka by oceanic water. On 24th October (no earlier data) $0.5-1.5 \mathrm{mg} \mathrm{m}^{-3}$ pigment prevailed east of Box D, again connected with India but not Sri Lanka.

In conclusion, during 1979-1981, nutrientand phytoplankton-rich water exported from the upwelling along southwest India may have reached 5 or $6^{\circ} \mathrm{N}$ in the area east of Box $\mathrm{D}$, but most of the time it did not enter Box D. From the relatively poor temporal CZCS coverage even during these years with frequent observations, however, it is not clear whether there are preferred advective times within the SW monsoon season. Yapa (2000) has depicted the CZCS climatology 1978-1986 in three figures for October-May east of $78^{\circ} \mathrm{E}$ showing offshore uniformly pigment-poor water $(<0.06$ to about 0.15 or $0.20 \mathrm{mg} \mathrm{m}^{-3}$ ) from December through May. March-May with largely $<0.06 \mathrm{mg} \mathrm{m}^{-3}$ were especially poor. Offshore, the OctoberNovember picture shows $0.06-0.5 \mathrm{mg} \mathrm{m}^{-3}$ of pigment south of $7^{\circ} \mathrm{N}$, but between 7 and $8^{\circ} \mathrm{N}$ values $>0.5 \mathrm{mg} \mathrm{m}^{-3}$ extending plume-like from the west to $79^{\circ} \mathrm{E}$. This climatology confirms our observations. 


\subsubsection{Advection to offshore during the $S W$ monsoons of 1982-1985 and 1997-2001}

After the dismantling of the CZCS processing system, small-size pictures of pigment distributions on all available individual days were inspected for June-November of 1982 to 1985. Since neither longitude nor latitude, or even outlines of the boxes could be drawn, the remarks about the extent of pigment plumes, etc., are imprecise. Moreover, there were no observations for the region prior to late July 1985, late August 1984, early September 1982, and late October 1983 (excepting a few days in mid-July). As found for late 1978 through 1981, the open Laccadive Sea during these periods had low pigment content $\left(<0.1\right.$ to ca. $\left.0.2 \mathrm{mg} \mathrm{m}^{-3}\right)$. During each of the four years, plumes or other outbreaks were present only from approximately the middle of the west coast $\left(\right.$ ca. $\left.15^{\circ} \mathrm{N}\right)$ and to the south. In all, 57 days provided reasonably clear views, but 13 were discounted because the same features were observed on adjoining dates. During the remaining 44 days, outbreaks or plumes (usually more than one at a time) were present on $2 / 3$ of them. In about $3 / 5$ of the cases, pigment concentrations did not rise beyond $0.4-0.8 \mathrm{mg} \mathrm{m}^{-3}$, while in $2 / 5$, values exceeded 1 and reached to about $3 \mathrm{mg} \mathrm{m}^{-3}$. Several plumes originated near Cape Comorin, the southern tip of India, and were directed to the southwest or south. Almost no outbreak appeared to have the form of filaments as, e.g., off Arabia, the exception being one date each off Goa and Cape Comorin during November 1983.

Inspection of monthly SeaWiFS maps from September 1997 through December 2001 confirmed that zonal, large outbreaks from the shelf into chlorophyll-poor water, as well as plumes originating at Cape Comorin and directed south- or southeastward are not uncommon, especially during the SW monsoon. During that season, the pigment concentrations in the zonal outbreaks often were $1-3 \mathrm{mg} \mathrm{m}^{-3}$ but rarely reached $5 \mathrm{mg} \mathrm{m}^{-3}$, while those in the plumes near Cape Comorin often were $\geq 5 \mathrm{mg} \mathrm{m}^{-3}$. During the NE monsoon and the following intermonsoon, the concentrations in the open Laccadive Sea at large appeared to range mostly between 0.2 and $0.4 \mathrm{mg} \mathrm{m}^{-3}$ and, thus, were higher than reported herein for the CZCS observations of the earlier years. We cannot offer an explanation.

\subsubsection{Incidental observations of the island chains}

In section 3.1, when discussing figure 2, the occurrence of relatively rich water around the Maldive
Islands during October 1979 was pointed out. Similar pigment concentrations were observed once in early November 1979 for the Laccadive Islands. In contrast, during all of June 1979, during mid-June to early July 1980, and in late June 1981, the entire archipelago of the Maldives was filled with "blue" (see color bar in figure 2) water of oceanic pigment content.

\section{Discussion}

\subsection{Absence of indigenous offshore phytoplankton blooms and the seasonal cycle in the mixed layer}

This paper is the first to describe a seasonal progression and interannual variation of near-surface phytoplankton pigment for the offshore region of the Laccadive Sea. The principal finding is that during 1979-1981, the seasonal pattern of CZCS-derived phytoplankton concentrations followed that of the low-nutrient offshore eastern, but not the western and northern Arabian Sea. With the qualification that there were very few data for the first two months of the SW monsoon, regular open-sea blooms were not observed. Visual inspection of all images for the SW monsoon seasons in the broad sense of 1982-1985 and the monthly SeaWiFS images for September 1997 through 2001 suggests the same. For the NE monsoon season, the absence of regular open-sea blooms can also be regarded as a recurring feature in view of eight years of CZCS observations in Area 2B (figure 1) to the west of the Laccadive Islands or Lakshadweep (Banse and English 2000).

The seasonal progression of satellite-observed pigment, when unaffected by advection from the shelf, comprised the following pattern during the three years with good coverage: Fairly low concentrations during the NE monsoon period; annual minimum concentrations during the subsequent intermonsoon period; a mild increase prior to the SW monsoon; and fairly low pigment levels during the SW monsoon including, probably, the transition to the NE monsoon (not distinguished herein from the SW monsoon season proper). The low levels during the SW monsoon are camouflaged in the means in figures $3-7$ by the localized outbreaks of phytoplankton-rich shelf water. Box D was least influenced by such intrusions of pigmentrich water during the SW monsoon while the region adjoining the box to the east was much affected by advection from the southwest Indian shelf. 
The seasonal aspects of phytoplankton development may be understood qualitatively from the physical oceanography, while the actual level and the rate of change of phytoplankton concentrations are principally affected by biological processes. During the NE monsoon the isothermal layer above the pycnocline is stratified by salinity so that the supply of nutrients from below will be small. The advection of low-salinity water from the south and east seems to be the principal difference from most of the Arabian Sea, except for the southeast which adjoins the Laccadive Sea. In fact, Colborn (1975) had included a large region south of Area 2 (figure 1 , herein), reaching beyond $70^{\circ} \mathrm{E}$, in the hydrographic regime of the Laccadive Sea (his Area 11). The renewed heating and the establishment of a seasonal thermocline in February-March reduce the supply of nutrients from below. Presumably, the lowering of pigment concentration during this time, observed also over much of the southern and central Arabian Sea, is connected with it.

The slight (non-significant, but persistent) increase of pigment in May-June, prior to the SW monsoon, is without an obvious environmental correlate. Offshore, a lowering of temperature from April to May is not apparent (Hastenrath and Lamb 1979 for 1911-1970); the salinity pattern is not known on a monthly scale. However, during the period the low-salinity regime is replaced by water from the north, at least along the coast. It might lead to a less stratified water column above the principal pycnocline or the seabed and a slightly enhanced nutrient supply.

The SW monsoon season cannot be characterized well in this study by only looking at the pigment means (table 1) even when data are available; during this time, the ranges of the daily means (table 1 ) and the S.D. in figures 3-6 indicate great variability. To an appreciable degree the variability is spatial, not temporal, as indicated by the daily S.D. in the figures and the discussion in section 3 based on visual inspection. Perhaps, Box D with its low means and small variability also is representative for the northern boxes outside of advected plumes or filaments containing shelf water. Even during 1979, the year with the highest means in boxes $\mathrm{T}-\mathrm{C}$, the seasonal mean in Box $\mathrm{D}$ for the SW monsoon was close to the means west of the Laccadive Islands for the same interval (areas 2B and $\mathrm{C}$ in Banse and English, 2000: table 1): 0.16 to $0.20 \mathrm{mg} \mathrm{m}^{-3}$ for $1979-1981$ in Box $\mathrm{D}$, versus averaged monthly means of daily means for 1979 1986 of $0.16 \pm 0.13$ and $0.14 \pm 0.06 \mathrm{mg} \mathrm{m}^{-3}$ in areas $2 \mathrm{~B}$ and C. Finally, it is clear from figures 3-6 for boxes $\mathrm{T}-\mathrm{C}$ that average pigment concentrations and variability rapidly decline after mid-October. This period is often called the post-monsoon season.
Interannual differences for the SW monsoons of 1979-1981 (and also for late 1978) are marked (cf. table 1), but we have no explanation. The cause is likely to have operated on a scale beyond the Laccadive Sea, since higher monthly median concentrations of pigment also occurred during the 1979 season in the eastern Arabian Sea (Area 2 in Banse and English 2000). In fact, the local, daily upwelling indices calculated from wind (Thadathil et al 1997) for Marmagoa (Goa, $15^{\circ} \mathrm{N}$ ) and Mangalore $\left(13^{\circ} \mathrm{N}\right)$ do not show conspicuous differences among 1979, 1980, and 1981. However, 1979 , the richest year in terms of pigment concentrations and the best in terms of visibility (i.e., relatively low cloud cover over the Laccadive Sea even during August and September), was a year with very low monsoonal rainfall along the west coast (Sadhuram et al 1991) and for all of India (Webster et al 1998: figure 19a). In contrast, 1981 was the poorest year for pigment and had an average precipitation, and 1980 was intermediate in pigment and rainfall. It is to be seen from future data, whether this was a coincidence or will recur.

Note that the timing of the seasonal progression of phytoplankton in a nutrient-constrained habitat can be satisfactorily elucidated from physical observations. The rate of change and the concentration achieved, however, are principally a function of the balance between the rates of cell division and grazing (see Banse 1994: section 3.2; new grazing data from the Arabian Sea in Landry et al 1998; Brown et al 1999; Caron and Dennett 1999) and, perhaps, grazing thresholds (Lessard and Murrell 1998). The exception is the presence of strong horizontal gradients of pigment, like those in filaments or plumes, where eddy diffusion also may be a major loss or gain term.

The present result about absence of regular offshore blooms of phytoplankton in the Laccadive Sea is in contrast to the model calculations by McCreary et al (1996) who deduced a marked bloom for the NE monsoon. In our opinion, their conclusion was the result of using only temperature data for judging depth changes of the mixed layer. The mixed layer in the model appeared to deepen from seasonal cooling and thus simulated a high nutrient supply to the surface layer (cf. the similarly temperature-derived mixed-layer depths in the same region in Wyrtki 1971; Colborn 1975; Hastenrath and Greischar 1989; Rao et al 1989). Actually, the cooled isothermic layer above the main pycnocline is stratified by low salinity during this time. The water is advected from the Bay of Bengal (see Darbyshire 1967: figure 13; Wyrtki 1971: charts 50, 51 and sections on pp. 440, 494, 497; Varkey et al 1979: figure 
3) and must be poor in nutrients. The apparent absence of an indigenous phytoplankton bloom in the open Laccadive Sea during the SW monsoon in Box $\mathrm{B}$ and to the north also is contrary to the calculations by McCreary et al (1996), but the reason is not obvious. Since the modeled tongue of high pigment expanded against the prevailing current, the mechanism in the model must have been in situ growth rather than advection. However, there are few CZCS observations for the first two months of the SW monsoon. An earlier CZCS-based map for September 1979 (Goes et al 1992) depicted high pigment clearly extending beyond the shelf south of approximately $12^{\circ} \mathrm{N}$, the northern border of Box B. The reported concentrations, however, were much higher than those calculated herein from the same CZCS measurements (cf. boxes $\mathrm{B}$ and $\mathrm{C}$ in section 3.2), so that the earlier processing may need to be reexamined.

\subsection{Advection of shelf water to offshore}

Next in importance to the stated absence of indigenous offshore blooms is that the effect of the Indian upwelling of the SW monsoon on the phytoplankton was essentially restricted to the shelf during 1979-1981 and north of 8 to $9^{\circ} \mathrm{N}$ (northern Box $\mathrm{C} /$ border to Box B). This was not expected, since the hydrographic sections in Johannessen et al (1981) and Madhupratap et al (1990) show seasonal uplift of the principal pycnocline well beyond $200 \mathrm{~km}$ from the shore, and those by Ramamirtham and Rao (1974) well beyond the 200-m isobath. On the other hand, hydrography, nutrients, and biota for the few available in situ offshore data of this season indicate that the upwelled, nutrientenriched water rarely extends far beyond the shelf break (e.g., Johannessen et al 1981; Madhupratap et al 1990; Shetye et al 1990; Goes et al 1992; Pant 1992). The physical mechanism that would contain the surface water on the shelf during much of the time, in spite of coastal divergence, is not clear. Most of the cross-shelf sections by Ramamirtham and Rao (1974) for June-August 1962 do not suggest a shelf-front (granted that the station spacing was wide), while Johannessen et al (1981: figure 6) for August 1974 mapped a marked horizontal salinity gradient extending from 10 to $17^{\circ} \mathrm{N}$

Thus, intrinsically the open Laccadive Sea is nutrient-poor year-round. Individual instances of advection, however, may carry plankton-rich water far beyond the shelf, especially south of Box B and east of Box D, as seen from the outbreaks of phytoplankton-rich water between late 1978 through 1981 during and shortly after the SW monsoon season. Inspection of images of 1982-1985 and 1997-2001 suggested that such transport of water from the shelf is fairly common during this time. Any water moved off the shelf will carry with it zooplankton and fish larvae from a highly productive regime into one with scant food supply, presumably beyond the point of physical and, for many species, of biological (starvation and death) return. How much of the year-class variability of oil sardines and mackerel off southwest India has to do not only with the number of egg-laying females, the growth rate and grazing mortality of the larvae while on the shelf, but also with whole-sale loss by advection? While satellites cannot answer the question, the connection between hydrography, nutrient supply, plankton development, and year-class strength of fishes spawning during the SW monsoon season cannot be investigated from ships alone because of the difficulty of being in the right place at the right time.

The nutrient-poverty of the Laccadive Sea in the region of Boxes $\mathrm{C}-\mathrm{D}$ is especially remarkable during the SW monsoon because of the wide cyclonic eddy modeled by Shankar and Shetye (1997), which would facilitate upward nutrient transport in its center. The July climatology (1998-2001) of SeaWiFS shows a "finger" (lobe or filament?) of ca. $2-5 \mathrm{mg} \mathrm{m}^{-3}$ extending across half of the Laccadive Sea at approximately $9-10^{\circ} \mathrm{N}$ (Box B). The only possible in situ confirmation was made by Shetye et al (1990: figure 12) in June 1987 when $3.2 \mathrm{mg} \mathrm{m}^{-3}$ surface chlorophyll occurred south of the center of our Box C in an area of strong current shear (Sumitra-Vijayaraghavan's data in Banse et al 1996).

\subsection{Concluding remarks}

Our study was done prior to the launch of another, better color satellite, the SeaWiFS. The work was qualitative in the sense that

- quantitative reasons for the waxing and waning in the seasonal patterns could not be presented;

- the advective features had to be inferred from using pigment as a tracer because of the lack of concurrent physical data, e.g., sea surface temperature (SST) or sea surface height. (We had attempted SST processing but it did not yield convincing results, see Lierheimer 1997.)

As mentioned in the Introduction, the mode and location of the discharge from the Indian shelf of surface water displaced by coastal upwelling are unknown. While the mechanisms of the zonal outbreaks seen in the pigment fields need to be investigated in situ, a study of weekly or biweekly Sea- 
WiFs images, available for more than four years, might be worthwhile for discerning whether the outbreaks are confined to a few localities even along a rather featureless coast as off southwest India. The general absence of pigment filaments as present during the upwelling off Oman or California, where they are associated with capes and are caused by strong physical movements and fronts, suggests a different physical regime. The Indian region also is subject to heavy rain and river runoff during the upwelling season, in contrast to almost all other areas worldwide. Such work with satellite data, while interesting in itself, would help focus future comprehensive studies of shelf hydrography and associated pelagic biology. Depending on the weather, concurrent satellite observations would certainly be useful in guiding the ship(s) while at sea.

\section{Acknowledgements}

We wish to acknowledge gratefully the funding over the years by the University of Washington Graduate Opportunity Program to LJL, the NASA Graduate Student Researchers Program to LJL, NASA grant NAWG 3606 to KB, and ONR grant N00014-93-1-0064 to KB. LJL wishes to thank D L Martin and M J Perry for their help. Both of us are indebted to D C English and the NASA data archives at GSFC, Greenbelt, MD (now, DAAC). We also benefited from advice and criticism by three anonymous reviewers.

\section{APPENDIX}

\section{A.1 Check of the atmospheric correction}

The Global Data Set uses a default atmospheric correction coefficient (epsilon) of 1.0. To check whether a marine or continental aerosol may be dominant in a particular scene causing an error, an individual epsilon was calculated for 46, 2-min scenes from 1978-1979 (years arbitrarily chosen) for a so-called KMG product. Raw $4-\mathrm{km}$ resolution Level I (i.e., calibrated satellite radiances, also obtained from NASA) scenes were reprocessed with the University of Miami's DSP system. Channel $4(670 \mathrm{~nm})$ was used to identify clouds and haze subjectively. Pigment means and standard deviations from the FM4 product were calculated for the valid pixels not located close to clouds or haze. A new epsilon was then chosen from areas of low chlorophyll $\left(<0.25 \mathrm{mg} \mathrm{m}^{-3}\right.$, Gordon and Clark 1981) and applied. The pigment means and standard deviations were recalculated for the same pixels as for the FM4 product. The nonparametric Wilcoxon signed-rank tested for statistical differences between the two products at $p=0.05$.

Of the 46 scenes, 23 did not need a correction to the default value of 1.0 or could not be corrected because of the absence of low pigment values. For the others, the difference of mean pigment (FM4-KMG) between the boxes ranged between -0.03 and $0.08 \mathrm{mg} \mathrm{m}^{-3}$ (median, 0.0) for a range of pigment box means between 0.07 and $0.35 \mathrm{mg} \mathrm{m}^{-3}$. The products, however, did not differ at the $p=0.05$ level. Therefore, the default epsilon for the FM4 scenes was accepted, but note that the method could not be applied to the high pigment levels (always $>0.25 \mathrm{mg} \mathrm{m}^{-3}$ ) of the $\mathrm{SW}$ monsoon with its onshore winds.

\section{A.2 Application of additional algorithms to pigment data}

Two additional algorithms were applied to the 303 Level I, 4-km resolution scenes to obtain a so-called DM4 product. By pre-set criteria, the algorithms reject pixels that are suspect (but not necessarily false) because of multiple scattering interactions and possible cloud effects that include electronic overshoot of the sensor after passing over a large, bright cloud. The first algorithm (Martin and Perry 1994) corrects for multiple scattering interactions between Rayleigh and aerosol components by accounting for the viewing geometry of the satellite. The procedure uses a numerical simulation of the satellite track to calculate the error in Channel $1(440 \mathrm{~nm})$. Pixels with errors greater than 1.5 digital counts are rejected.

The second algorithm (English et al 1996) addresses the problem of cloud contamination by combining criteria for cloud ringing with tests for cloud element contamination and cloud edge effects. The history of the scan is incorporated in a regression equation and suspect pixels down-scan (east) of the cloud are removed. Pixels may also be contaminated when a cloud occupies only part of it, or if a pixel is too close to a cloud. In both cases, suspect pixels can occur on the up- and down-scan sides of the cloud. For example, in the lower left quadrant of figure 2 for 18th October 1979, most of the purple spots would have been eliminated by the algorithm. This removal of pixels suspect due to viewing geometry and cloud effects yields our so-called DM4 product. The FM4 and DM4 products were compared with three sets of pigment means from boxes A and D for DecemberJanuary, March-May, and July-October to test 


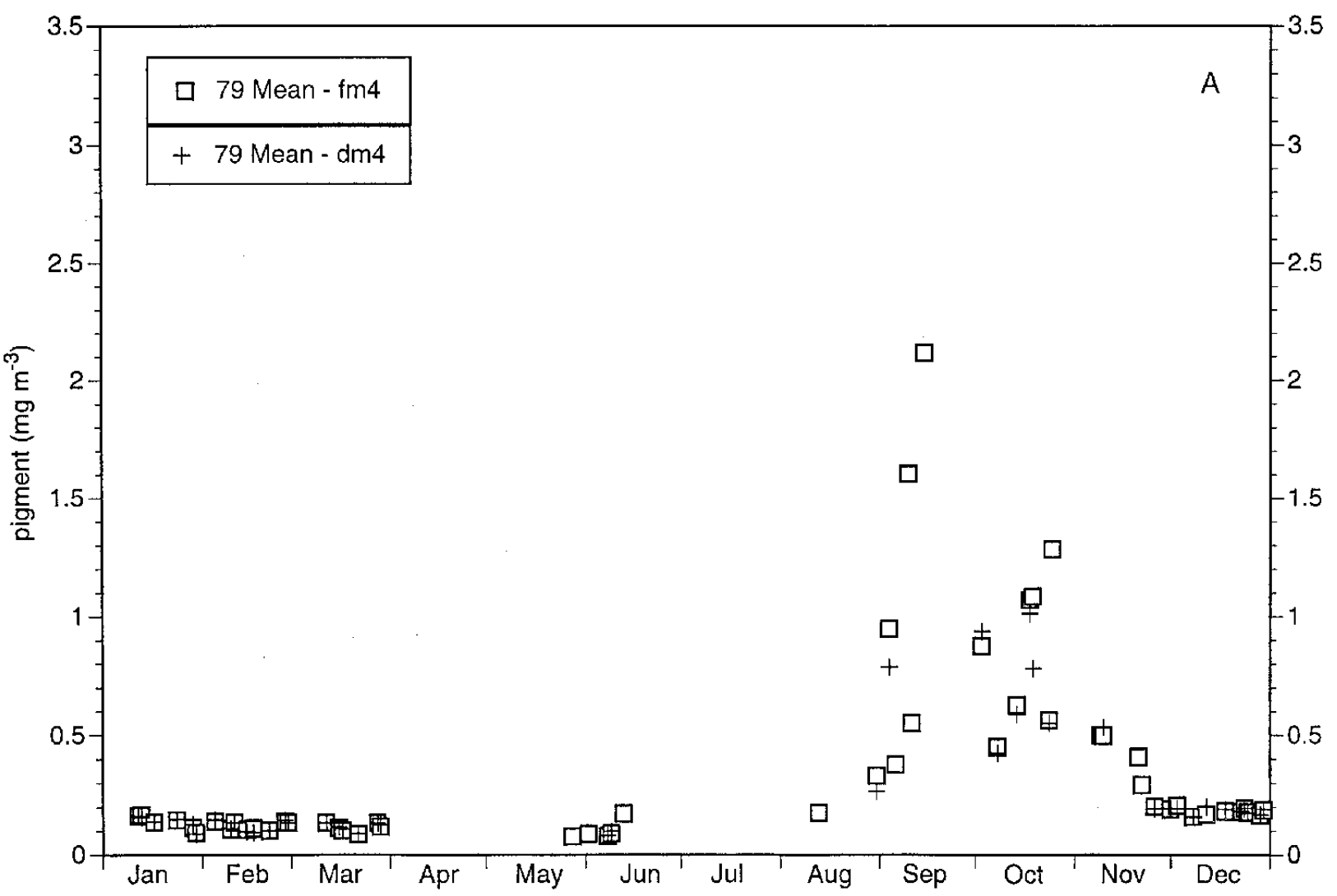

Figure 9. Daily FM4 and DM4 means of phytoplankton pigment in Box A during 1979. Note the linear ordinate.

which set should be used. The non-parametric Wilcoxon signed-rank test was applied to the six sets of daily pigment means $(p=0.05)$. The slopes and intercepts were also tested by the so-called GM regression (for geometric mean estimate of the functional regression; also called the standard major axis regression, Ricker 1973, 1975) because both the FM4 and DM4 products are afflicted by error so that one could not be regarded as the independent variable as in the ordinary linear regression.

The percentage of pixels suspect in the DM4 product on account of the viewing geometry ranged from $0-4 \%$ of the pixels in a scene. It was so low because the Laccadive Sea was in the far right of almost all of the scenes while the multiplescattering error is concentrated to the far left. In contrast, the percentage of pixels labeled in the DM4 product as suspect on account of cloud contamination ranged from 2-66\%. As an example for the overall results, figure 9 compares the FM4 and DM4 products for Box A in 1979. Lierheimer (1997, Appendix A) presents the data for all boxes and years. Notice that there are fewer DM4 images because often too many pixels were dropped by our cut-off specification to meet the $1 \%$ criterion for inclusion in the data set. This was especially so during the SW monsoon when the sea was often visible only through breaks of the cloud cover even in the FM4 images. For example, in figure 9, of the six FM4 values $>0.9 \mathrm{mg} \mathrm{m}^{-3}$, which might be considered as representing blooms, five are not matched by DM4 values. Hence, the FM4 concentrations for these five dates are suspect but cannot be shown to be incorrect. Specifically, the differences for the 46 dates in figure 9 with both products are as follows: For 35 low-value pairs between mid-November and June, the pigment concentrations of the FM4 and DM4 products range from 0.08 to $0.21 \mathrm{mg} \mathrm{m}^{-3}$ (median, 0.13) and from 0.07 to $0.20 \mathrm{mg} \mathrm{m}^{-3}$ (median, 0.13), respectively. For the 11 pairs of the period with high pigment values, the FM4 and DM4 products range from 0.33 to $2.12 \mathrm{mg} \mathrm{m}^{-3}$ (median, 0.63) and from 0.27 to $2.25 \mathrm{mg} \mathrm{m}^{-3}$ (median 0.59), respectively. There were no significant differences between the pairs in each group.

Important is that the corrections and loss of days did not change the structure of the seasonal signals. This holds also for the other boxes and dates. Further, for the days with FM4 and DM4 products, even the probably contaminated FM4 means tended to be similar to the DM4 means. Figure 9, however, does not depict that the standard deviations for the DM4 means were much lower than those for the FM4 means, as 
shown by Banse and English (1993) for the northwestern Arabian Sea. Thus, the DM4 product would permit the study of finer differences between means and enhance confidence in the interpretations.

Because of the importance of distinguishing and choosing correctly between the FM4 and DM4 products, the GM regressions were calculated for the three seasons for boxes A and D. The boxes almost represent the latitudinal range of the present study. The squared correlation coefficients ranged from 0.72 to 0.99 (median, 0.90). More importantly, the slopes of the six regressions did not differ from unity and the intercepts did not differ from zero, although the confidence intervals for both were large during the July-October period $\left(r^{2}=0.72\right.$ and 0.86 for boxes $\mathrm{A}$ and $\mathrm{D}$, respectively). The DM4 processing does not lower all high FM4 values as such, as might be read from figure 9 . In fact, in other years or boxes during the SW monsoon, the higher pigment concentrations $\left(0.5-2.5 \mathrm{mg} \mathrm{m}^{-3}\right.$ for entire boxes) were sometimes obtained from the DM4 procedure. Notice the uncertainty about comparisons between FM4 and DM4 products in our test for high box means or true blooms, since the highest pigment concentrations in five of the sets were $0.35 \mathrm{mg} \mathrm{m}^{-3}$, and only about $1.0 \mathrm{mg} \mathrm{m}^{-3}$ in the sixth. The procedure cannot identify which pixels are incorrect but removes all suspect pixels.

In view of the acceptability of the default epsilon of the FM4 processing and the satisfactory accuracy of the FM4 values relative to the DM4 product, at least at the concentrations checked, the Level II, FM4 product as in the NASA Global Data Set was chosen for further analysis, because more days were available especially during the SW monsoon season. This is in contrast to Banse and English $(1993,2000)$ who used the DM4 product for the Arabian Sea, in order to work with fewer data but with lower standard deviations, without testing the necessity, as done here.

\section{A.3 Pigment trends within and among boxes}

After accepting the FM4 product as adequate for our purpose, the non-parametric Kruskal-Wallis test determined whether significant seasonal or interannual differences of mean pigment occurred within each box. Seasons were defined as stated previously, with December being the data from the preceding year. November 1978 and December 1981 were not included in the seasonal summaries.
A Tukey-type non-parametric multiple comparison for unequal sample sizes (Zar 1984) helped identify significant seasonal or interannual differences. As no data were available for the 197879 NE monsoon in Box D, the unpaired MannWhitney test, instead of the Kruskal-Wallis test, examined seasonal and interannual differences. The same approach was applied to within-box comparisons as used for among-box comparisons. The significance level for all tests was set at $p=0.05$.

\section{References}

Banse K 1994 On the coupling of hydrography, phytoplankton, zooplankton and settling organic particles offshore in the Arabian Sea; Proc. Indian Acad. Sci. (Earth Planet. Sci.) 103 125-161

Banse K and English D C 1993 Revision of satellite-based phytoplankton pigment data from the Arabian Sea during the northeast monsoon; Mar. Sci. (Pakistan) 2 83-103

Banse K and English D C 2000 Geographic differences in seasonality of CZCS-derived phytoplankton pigment in the Arabian Sea for 1978-1986; Deep-Sea Res. II 47 $1623-1677$

Banse K, Sumitra-Vijayaraghavan and Madhupratap M 1996 On the possible causes of the seasonal phytoplankton blooms along the west coast of India Indian J. Mar. Sci. 25 283-289

Bhargava R M S, Bhattathiri P M A, Devassy V P and Radhakrishna K 1978 Productivity studies in the southeastern Arabian Sea; Indian J. Mar. Sci. 7 267-270

Bhattathiri P M A and Devassy V P 1979 Biological characteristics of the Laccadive Sea (Lakshadweep); Indian $J$. Mar. Sci. 8 222-226

Brown S L, Landry M R, Barber R T, Campbell L, Garrison D L and Gowing M M 1999 Picophytoplankton dynamics and production in the Arabian Sea during the 1995 southwest monsoon; Deep-Sea Res. II 46 $1745-1768$

Bruce J G, Johnson D R and Kindle J C 1994 Evidence for eddy formation in the eastern Arabian Sea during the northeast monsoon; J. Geophys. Res. 99C 7651-7664

Bruce J G, Kindle J C, Kantha L H, Kerling J L and Bailey J F 1998 Recent observations and modeling in the Arabian Sea Laccadive High region; J. Geophys. Res. 103C 7593 7600

Caron D A and Dennett M R 1999 Phytoplankton growth and mortality during the 1995 northeast monsoon and spring intermonsoon in the Arabian Sea; Deep-Sea Res. II 46 1665-1690

Colborn J G 1975 The Thermal Structure of the Indian Ocean (Honolulu: East-West Center Press, University of Hawaii) $173 \mathrm{p}$

Darbyshire M 1967 The surface waters off the coast of Kerala, south-west India; Deep-Sea Res. 14 295-320

English D C, Banse K, Martin D L and Perry M J 1996 Electronic overshoot and other bias in the CZES Global Data Set: comparison with ground truth from the subarctic Pacific; Int. J. Remote Sensing $\mathbf{1 7}$ $3157-3168$

Evans R H and Gordon H R 1994 Coastal zone color scanner "system calibration": a retrospective examination; $J$. Geophys. Res. 99C 7293-7307 
Goes J I, Gomes H do R, Kumar A, Gouveia A, Devassy V P, Parulekar A H and Rao L V G 1992 Satellite and ship studies of phytoplankton along the west coast of India; In: Oceanography of the Indian Ocean (ed) B N Desai (New Delhi: Oxford \& IBH Publishing Co) pp. $67-80$

Gordon H R and Clark D K 1981 Clear water radiances for atmospheric correction of Coastal Zone Color Scanner imagery; Applied Optics 20 4175-4180

Gordon H R, Clark D K, Brown J W, Brown O B, Evans R $\mathrm{H}$ and Broenkow W H 1983 Phytoplankton pigment concentrations in the Middle Atlantic Bight: comparison of ship determinations and CZCS estimates; Applied Optics 22 20-36

Hareesh Kumar P V and Mathew B 1997 Salinity distribution in the Arabian Sea; Indian J. Mar. Sci. 26 271-277

Hastenrath S and Lamb P P 1979 Climatic Atlas of the Indian Ocean. Part I: Surface Climate and Atmospheric Circulation (Madison, WI: University of Wisconsin Press) $117 \mathrm{p}$.

Hastenrath S and Greischar L L 1989 Climatic Atlas of the Indian Ocean. Part III: Upper-Ocean Structure (Madison, WI: University of Wisconsin Press) 273p.

Johannessen O M, Subbaraju G and Blindheim J 1981 Seasonal variations of the oceanographic conditions off the southwest coast of India during 1971-1975; Fiskdirekt. Skr. Ser. Havunders. 18 247-261

Krey J and Babenerd B 1976 Phytoplankton Production. Atlas of the International Indian Ocean Expedition (Kiel: Institut f. Meereskunde, Kiel University \& Paris: Unesco) $70 \mathrm{p}$.

Landry M R, Brown S L, Campbell L, Constantinou J and Hongbin Liu 1998 Spatial patterns in phytoplankton growth and microzooplankton grazing in the Arabian Sea during monsoon forcing; Deep-Sea Res. II 45 $2353-2368$

Lessard E J and Murrell M C 1998 Microzooplankton herbivory and phytoplankton growth in the northwestern Sargasso Sea; Aquatic Microb Ecol. 16 173-188

Lierheimer L J 1997 Seasonal and Interannual Variability of Phytoplankton in the Laccadive Sea as observed by the Coastal Zone Color Scanner; M Sci Thesis (Seattle, WA: University of Washington) 98p. (Deposited also in the libraries of the National Institute of Oceanography, Dona Paula, Goa, and Central Marine Fisheries Research Institute, Cochin)

Madhupratap M, Sreekumaran Nair S R, Haridas P and Padmavati G 1990 Response of zooplankton to physical changes in the environment: coastal upwelling along the central west coast of India; J. Coast. Res. 6 413-426

Madhupratap M, Haridas P, Ramaiah N and Achuthankutty C T 1992 Zooplankton of the southwest coast of India: abundance, composition, temporal and spatial varability in 1987; In: Oceanography of the Indian Ocean (ed) B N Desai (New Delhi: Oxford \& IBH Publishing Co) pp. 99112

Martin D L and Perry M J 1994 Minimizing meteorologically-induced sensor response errors in CZCS Level IIA imagery; J. Geophys. Res. 99C 7309-7322

Mathew K J, Naomi T S, Antony G, Vincent D, Anilkumar R and Solomon K 1990 Studies on zooplankton biomass and secondary and tertiary production of the EEZ of India; In: Proc. First Workshop Scient. Res. FORV Sagar Sampada, 5-7 June, 1989 (ed) K J Mathew (Cochin: Central Mar. Fish. Res. Inst.) pp. 59-69

McCreary J P, Kundu P K and Molinari R L 1993 A numerical investigation of dynamics, thermodynamics and mixed-layer processes in the Indian Ocean; Prog. Oceanogr. 31 181-244

McCreary J P, Kohler K E, Hood R R and Olson D B 1996 A four-component ecosystem model of biological activity in the Arabian Sea; Prog. Oceanogr. 37 193-240

Morel A and Berthon J-F 1989 Surface pigment, algal biomass profiles, and potential production of the euphotic layer: Relationships reinvestigated in view of remotesensing applications; Limnol. Oceanogr. 34 1545-1562

Muraleedharan P M and Prasanna Kumar S 1996 Arabian Sea upwelling - a comparison between coastal and open ocean regions; Curr. Sci. $71842-847$

Pant A 1992 Primary productivity in coastal and off-shore waters of India during two southwest monsoons, 1987 and 1989; In: Oceanography of the Indian Ocean (ed) B N Desai (New Delhi: Oxford \& IBH Publishing Co) pp. 8190

Platt T and Herman A W 1983 Remote sensing of phytoplankton in the sea: surface-layer chlorophyll as an estimate of water-column chlorophyll and primary production; Int. J. Remote Sensing 4 343-351

Prasanna Kumar S, Snaith H, Challenor P and Guymer H T 1998 Seasonal and inter-annual sea surface height variations of the northern Indian Ocean from the TOPEX/POSEIDON altimeter; Indian J. Mar. Sci. $\mathbf{2 7}$ $10-16$

Ramamirtham C P and Rao D S 1974 On upwelling along the west coast of India; J. Mar. Biol. Ass. India 15 306317

Rao R R, Molinari R L and Festa J F 1989 Evolution of the climatological near-surface thermal structure of the tropical Indian Ocean: I. Description of mean monthly mixed layer depth, and sea surface temperature, surface current, and surface meteorological fields; J. Geophys. Res. 94C $10,801-10,815$

Ricker W E 1973 Linear regression in fishery research; J. Fish. Res. Board Can. 30 409-434

Ricker W E 1975 A note concerning Professor Jolicoeur's comments; J. Fish. Res. Board Can. 32 1494-1498

Sadhuram Y, Ramesh Babu V, Gopalakrishna V V and Sarma S S 1991 Association between premonsoonal SST anomaly field in the eastern Arabian Sea and subsequent rainfall over the west coast of India; Indian J. Mar. Sci. 20 106-109

Sen Gupta R, Braganca A, Noronha R J and Singbal S Y S 1980 Chemical oceanography of the Arabian Sea: Part V - Hydrochemical characteristics off the central west coast of India; Indian J. Mar. Sci. 9 240-245

Shankar D 1998 Low-frequency variability of sea level along the coast of India; Ph. D. thesis (Goa: Goa University) $207 \mathrm{p}$.

Shankar D and Shetye S R 1997 On the dynamics of the Lakshadweep high and low in the southeastern Arabian Sea; J. Geophys. Res. 102C 12,551-12,562

Shetye S R, Gouveia A D, Shenoi S S C, Sundar D, Michael G S, Almeida A M and Santanam K 1990 Hydrography and circulation off the west coast of India during the southwest monsoon 1987; J. Mar. Res. 48 359378

Shetye S R, Gouveia A D, Shenoi S S C, Michael G S, Sundar D, Almeida A M and Santanam K 1991 The coastal current off western India during the northeast monsoon; Deep-Sea Res. 38 1517-1529

Silas E G 1972 Investigations on the deep scattering layers in the Laccadive Sea; In: Proc. Sympos. Corals \& Coral Reefs (eds) C Mukundan and G S G Pillai (Cochin: Mar. Biol. Ass. India) pp. 257-274

Singh R V, Khambadkar L R, Nandakumar A and Murty A V S 1990 Vertical distribution of phos- 
phate, nitrate and nitrite of Lakshadweep waters in the Arabian Sea; In: Proc. First Workshop Scient. Res. FORV Sagar Sampada, 5-7 June, 1989 (ed) K J Mathew (Cochin: Central Mar. Fish. Res. Inst.) pp. 19-23

Thadathil P, Pattanaik J and Gosh A K 1997 An Atlas of upwelling indices along east and west coast of India (Dona Paula, Goa: Indian Nat. Oceanogr. Data Centre, Nat. Inst. Oceanogr.) 53p.

Varkey M J, Kesava-Das V and Rama-Raju D V 1979 Physical characteristics of the Laccadive Sea (Lakshadweep); Indian J. Mar. Sci. 8 203-210
Webster P J, Mangaña V O, Palmer T N, Shukla J, Tomas R A, Yanai M and Yasunari T 1998 Monsoons: Processes, predictability, and the prospects of prediction; J. Geophys. Res. 103C 14,451-14,510

Wyrtki K 1971 Oceanographic Atlas of the International Indian Ocean Expedition (Washington, DC: National Science Foundation) 531p.

Yapa K K A S 2000 Seasonal variability of sea surface chlorophyll-a of waters around Sri Lanka; Proc. Indian Acad. Sci. (Earth Planet. Sci.) 109 427-432

Zar J H 1984 Biostatistical Analysis (Englewood Cliffs, NJ: Prentice Hall) 718p.

MS received 22 February 2001; revised 15 March 2002 